\title{
A global three-dimensional model of tropospheric sulfate
}

\section{Citation}

Chin, Mian, Daniel J. Jacob, Geraldine M. Gardner, Michael S. Foreman-Fowler, Peter A. Spiro, and Dennis L. Savoie. 1996. "A Global Three-Dimensional Model of Tropospheric Sulfate." Journal of Geophysical Research 101 (D13): 18667. doi:10.1029/96jd01221.

\section{Published Version}

doi:http://dx.doi.org/10.1029/96JD01221

\section{Permanent link}

http://nrs.harvard.edu/urn-3:HUL.InstRepos:14121829

\section{Terms of Use}

This article was downloaded from Harvard University's DASH repository, and is made available under the terms and conditions applicable to Other Posted Material, as set forth at http:// nrs.harvard.edu/urn-3:HUL.InstRepos:dash.current.terms-of-use\#LAA

\section{Share Your Story}

The Harvard community has made this article openly available.

Please share how this access benefits you. Submit a story.

\section{Accessibility}




\title{
A global three-dimensional model of tropospheric sulfate
}

\author{
Mian Chin, ${ }^{1}$ Daniel J. Jacob, Geraldine M. Gardner, \\ Michael S. Foreman-Fowler, ${ }^{2}$ and Peter A. Spiro ${ }^{3}$ \\ Division of Applied Sciences and Department of Earth and Planetary Sciences, Harvard University, Cambridge, \\ Massachusetts

\section{Dennis L. Savoie} \\ Division of Marine and Atmospheric Chemistry, Rosenstiel School of Marine and Atmospheric Science, University of \\ Miami, Miami, Florida
}

\begin{abstract}
A three-dimensional model is used to simulate the global tropospheric distributions of dimethylsulfide (DMS), $\mathrm{SO}_{2}, \mathrm{SO}_{4}{ }^{2-}$, and methanesulfonic acid (MSA). The model uses meteorological input from a general circulation model (GCM) developed at the Goddard Institute of Space Studies (GISS) with $4^{\circ} \times 5^{\circ}$ horizontal resolution, nine layers in the vertical, and a time resolution of 4 hours. Model results are compared with observations from surface sites, ships, and aircraft. The model reproduces generally to within $30 \%$ the observed $\mathrm{SO}_{2}$ and $\mathrm{SO}_{4}{ }^{2-}$ concentrations over the United States and Europe; these concentrations are highly sensitive to the supply of $\mathrm{H}_{2} \mathrm{O}_{2}$ as an in-cloud $\mathrm{SO}_{2}$ oxidant. Sulfate concentrations and wet deposition fluxes observed at remote marine sites can be accounted for using a global DMS source of $22 \mathrm{Tg} \mathrm{S} \mathrm{yr}^{-1}$ in the model. However, this source overestimates DMS air concentrations by a factor of 2 unless we assume the presence of another DMS oxidant besides $\mathrm{OH}$ and $\mathrm{NO}_{3}$. Inclusion of another DMS oxidant in our model also improves the simulation of the MSA to $\mathrm{SO}_{4}{ }^{2-}$ concentration ratio in marine air. Simulated $\mathrm{SO}_{4}{ }^{2-}$ concentrations in the northern hemispheric free troposphere are much lower than in previous global models and are more consistent with the few observations available. The difference reflects in part our accounting of efficient scavenging of $\mathrm{SO}_{2}$ and $\mathrm{SO}_{4}{ }^{2-}$ in wet convective updrafts. Global mean tropospheric lifetimes computed in our model are 1.0 days for DMS, 1.2 days for $\mathrm{SO}_{2}, 3.9$ days for $\mathrm{SO}_{4}{ }^{2-}$, and 6.2 days for MSA. Fossil fuel combustion and industrial activities represent $68 \%$ of global non-sea-salt sulfur emissions. About $50 \%$ of $\mathrm{SO}_{2}$ globally is converted to $\mathrm{SO}_{4}{ }^{2-}$ aerosol (principally by in-cloud oxidation) while the remainder is removed by deposition ( $30 \%$ by dry, $20 \%$ by wet). In-cloud oxidation of $\mathrm{SO}_{2}$ represents $85 \%$ of the global $\mathrm{SO}_{4}{ }^{2-}$ source.
\end{abstract}

\section{Introduction}

Human activities account for $60-80 \%$ of global emission of sulfur gases to the atmosphere according to current estimates [Watson et al., 1992]. Oxidation of sulfur gases produces sulfate aerosol, which is removed by deposition on a time scale of days. It has been argued that anthropogenic enhancements of sulfate aerosol over the past century could have caused a significant increase in planctary albedo, compensating regionally for the parallel increase in greenhouse radiative forcing [Charlson et al., 1992]. Assessing the climatic effect of sulfate aerosol is, however, made difficult by uncertainties in the sources and atmospheric chemistry of the sulfate precursors, by the large spatial heterogeneity of sulfate concentrations, and also by our limited understanding of indirect radiative effects associated with the sensitivity of cloud albedo to the supply of sulfate cloud condensation nuclei.

We present here a global, three-dimensional simulation of atmospheric sulfate and its precursors using a general circulation model

IUSRA, NASA Goddard Space Flight Center, Code 916, Greenbelt, Maryland 20771

Program in Atmospheric and Oceanic Sciences, University of Colorado, Boulder, Colorado 80307. 84112

Department of Mathematics, University of Utah, Salt Lake City, Utah

Copyright 1996 by the American Geophysical Union.

Paper number 96JD01221.

0148-0227/96/96JD-01221\$09.00
(GCM) developed at the Goddard Institute of Space Studies (GISS). Our purpose is to evaluate current understanding of sulfur sources, sinks, and chemistry by comparing model results to observed distributions of sulfate and its precursors. In a companion paper [Chin and Jacob, this issue], we will use the model to analyze the budget of anthropogenic sulfur over polluted continents and to assess the global extent of anthropogenic influence on sulfate.

Previous global three-dimensional models of atmospheric sulfur have been presented by Langner and Rodhe [1991], Penner et al. [1994], Pham et al. [1995], and Feichter et al. [1996]. Our model differs from these models in a number of ways, and comparison of the global sulfur budgets in the different models indicates a number of discrepancies which we will discuss here (section 4) and in the companion paper.

The model is described in section 2 and evaluated with observations in section 3. Global sulfur budgets are presented in section 4 . Conclusions are in section 5.

\section{Model Description}

\section{General}

The GISS GCM II [Hansen et al., 1983] has a horizontal grid resolution of $4^{\circ}$ latitude $\times 5^{\circ}$ longitude, with nine layers in the vertical extending from the surface to 10 mbar along a sigma coordinate. The three lowest layers are centered at approximately 
$250 \mathrm{~m}, 800 \mathrm{~m}$, and $1800 \mathrm{~m}$ above the surface. We use a 1-year record of GCM meteorological quantities with 4-hour resolution (Table 1) to drive an off-linc chemistry-transport model (CTM) replicating the dynamics of the GCM [Prather et al., 1987]. The CTM has been applied previously to the simulation of chlorofluorocarbons [Prather et al., 1987], ${ }^{85} \mathrm{Kr}$ [Jacob et al., 1987], methylchloroform [Spivakovsky et al., 1990], ${ }^{222} \mathrm{Rn}$ and ${ }^{210} \mathrm{~Pb}$ [Jacob and Prather, 1990; Balkanski and Jacob, 1990; Balkanski et al., 1992, 1993], O 3 [Jacob et al., 1993a,b; Chin et al., 1994], ${ }^{14} \mathrm{CO}$ [Spivakovsky and Balkanski, 1994], and ${ }^{7} \mathrm{Be}$ [Koch et al., 1996]. These simulations provide important reference points for documenting the model behavior. We participated recently in a community intercomparison of global models involving simulations of ${ }^{222} \mathrm{Rn}$ and other short-lived tracers (D.J. Jacob et al., Evaluation and intercomparison of global atmospheric transport models using ${ }^{222} \mathrm{Rn}$ and other short-lived tracers, submitted to Journal of Geophysical Research, 1996).

Five species are included in our simulation: (1) dimethyl sulfide (DMS) emitted mainly from the ocean, (2) methanesulfonic acid (MSA) produced by DMS oxidation, (3) $\mathrm{H}_{2} \mathrm{~S}$ emitted from the terrestrial biosphere, (4) $\mathrm{SO}_{2}$ emitted from anthropogenic activities and volcanoes as well as produced in the atmosphere by oxidation of DMS and $\mathrm{II}_{2} \mathrm{~S}$, and (5) secondary $\mathrm{SO}_{4}{ }^{2-}$ produced by oxidation of $\mathrm{SO}_{2}$. The simulation is conducted for a period of 15 months with 4-hour time steps, starting from low initial concentrations of DMS (0.1 parts-per-trillion by mole, or ppt), MSA $(0.1 \mathrm{ppt}), \mathrm{H}_{2} \mathrm{~S}(0.1$ $\mathrm{ppt})$, and $\mathrm{SO}_{2}(50 \mathrm{ppt})$. Initial $\mathrm{SO}_{4}{ }^{2-}$ concentrations are $3 \mathrm{ppt}$ in the

Table 1. Meterological Archive Used as Model Input

\begin{tabular}{ll}
\hline \multicolumn{1}{c}{ Variable } & Time Resolution \\
\hline Surface pressure & 4 hours \\
Temperature & 5 days \\
Wind velocity & 4 hours \\
Mixed layer depth $^{\mathrm{a}}$ & 4 hours \\
Convective events, column total $^{\mathrm{b}}$ & 4 hours \\
Convective events, vertical distribution $^{\mathrm{b}}$ & 5 days \\
Precipitation rates, surface $^{\mathrm{c}}$ & 4 hours \\
Precipitation rates, vertical distribution $^{\mathrm{c}}$ & 5 days \\
Cloud optical depth, column total $^{\mathrm{d}}$ & 4 hours \\
Cloud optical depth, vertical distribution $^{\mathrm{d}}$ & 5 days \\
Cloud volume fraction $^{\mathrm{e}}$ & 5 days \\
\hline
\end{tabular}

The archive represents 1 year of output from the GISS GCM II with $4^{\circ}$ $\mathrm{x} 5^{\circ}$ resolution, nine layers in the vertical, and resolution of the diurnal cycle [Hansen et al., 1983].

${ }^{a}$ Mean vertical extent of dry convective instability initiated by surface heating.

b Separate statistics are kept for the frequencies of dry, shallow wet, and deep wet convection events. Shallow wet convection is defined as not extending above layer 3 (about $2.6 \mathrm{~km}$ above the surface). The vertical distribution of convective events is computed at each 4-hour model time step by scaling the 5-day statistics to the 4-hour column totals. The convective mass fluxes are computed from the frequencies of convection events following Prather et al. [1987].

c Separate statistics are kept for convective and large-scale precipitation. Precipitation rates through the bottom of each layer are computed at each 4-hour model time step by scaling the 5-day averages to the 4-hour surface precipitation totals.

d Cloud optical depths in cach laycr are computcd at cach 4-hour time step by scaling the 5-day averages to the 4-hour column totals. The column total is also used to derive the solar irradiance at the surface for calculations of the dry deposition velocity and of sulfur emission by terrestrial vegetation.

${ }^{e}$ The volume fraction of cloud in a gridbox used for calculating aqueous phase $\mathrm{SO}_{2}$ oxidation is obtained as the ratio of cloud optical depth in the gridbox to the optical depth of large-scale clouds in the GCM [Hansen et al., 1983, equation (21)].
Table 2. Global Sulfur Emission for 1985

\begin{tabular}{|c|c|c|}
\hline Source & $\begin{array}{c}\text { Global } \\
\text { Emission, } \\
\mathrm{Tg} \mathrm{S} \mathrm{yr}^{-1}\end{array}$ & Reference \\
\hline $\begin{array}{l}\mathrm{SO}_{2} \\
\text { Fuel combustion and industrial } \\
\text { activities } \\
\text { Biomass burning } \\
\text { Aircraft } \\
\text { Noneruptive volcanoes } \\
\text { Eruptive volcanoes }{ }^{\mathrm{c}}\end{array}$ & $\begin{array}{r}65.0 \\
2.3 \\
0.1 \\
2.7 \\
4.0\end{array}$ & $\begin{array}{l}\text { Benkovitz et al. }[1996] \\
\text { Spiro et al. }[1992] \\
\text { G. McInnes }(1991)^{\mathrm{b}} \\
\text { Spiro et al. }[1992] \\
\text { This work }\end{array}$ \\
\hline $\begin{array}{l}\text { DMS } \\
\text { Ocean }^{\mathrm{d}} \\
\text { Terrestrial biosphere }^{\text {ing }}\end{array}$ & $\begin{array}{r}21.7 \\
0.1\end{array}$ & $\begin{array}{l}\text { This work } \\
\text { Spiro et al. [1992] }\end{array}$ \\
\hline $\begin{array}{l}\mathrm{H}_{2} \mathrm{~S} \\
\text { Terrestrial biosphere }\end{array}$ & 0.8 & Spiro et al. [1992] \\
\hline Total emission & 96.7 & \\
\hline
\end{tabular}

a Global Emissions Inventory Activity (GEIA) data base for 1985 emission with $1^{\circ}$ latitude $\times 1^{\circ}$ longitude resolution. Assumed constant throughout the year.

b Personal communication.

c Based on a volcanism chronology for 1985 [Simkin and Siebert, 1994]. The chronology gives for each eruption the volcanic explosivity index (VEI), the start date, and the duration in days. It also includes information on the locations and crater heights of individual volcanoes. The total amount of $\mathrm{SO}_{2}$ emitted by a given eruption, and the height of the eruption plume, are specified as functions of the VEI [Stoiber et al., 1987, Table 2; Simkin and Siebert, 1994, Table 4]. The emission is distributed evenly in time over the duration of the eruption, and evenly with altitude over the vertical extent of the eruption plume.

d Computed using the relation $F=k C$, wherc $F$ is the emission flux, $k$ is the sea-to-air transfer velocity of DMS, and $C$ is the seawater DMS concentration. The seasonal variation of seawater DMS concentrations is modeled as a sinusoidal function constrained to match the May October and November - April 6-month averages reported by Bates et al. [1987] for different latitudes (and longitudes in the tropics). The sea-to-air transfer velocity of DMS is computed as $k=k_{\mathrm{CO} 2} \times\left(S c_{\mathrm{DMS}} /\right.$ $\left.S c_{\mathrm{CO} 2}\right)^{n}$, where $k_{\mathrm{CO} 2}$ is the transfer velocity of $\mathrm{CO}_{2}, S c_{\mathrm{DMS}}$ and $S c_{\mathrm{CO} 2}$ are the Schmidt numbers of DMS [from Saltzman et al., 1993] and $\mathrm{CO}_{2}$ [from Erickson, 1993]. For an ocean surface with waves (wind speeds $>3.6 \mathrm{~m} \mathrm{~s}^{-1}$ ), we use $k_{\mathrm{CO} 2}=6.4 \mathrm{x}$ (windspeed - 3) [Tans et al., 1990, as given by Erickson, 1993]. For a smooth ocean surface (wind speed < $3.6 \mathrm{~m} \mathrm{~s}^{-1}$ ) we assume $k_{\mathrm{CO} 2}=1.07 \mathrm{x}$ windspeed. The value of $\mathrm{n}$ is $1 / 2$ for a wavy surface [Ledwell, 1984] and $2 / 3$ for a smooth surface [Deacon, 1977].

troposphere, $10 \mathrm{ppt}$ in the lower stratosphere (70-150 mbar), and $50 \mathrm{ppt}$ in the middle stratosphere (10-70 mbar). The first 3 months are used for initialization of the troposphere, and our analysis is focused on the last 12 months. Hydrogen sulfide accounts for less than $1 \%$ of the global sulfur source and does not play a significant role as $\mathrm{a} \mathrm{SO}_{4}{ }^{2-}$ precursor anywhere in the global model domain; it will not be discussed further, but it will be included in our final sulfur budget for completeness.

\section{Emission}

The global emission inventory used in the model is described in Table 2. The $\mathrm{SO}_{2}$ source of $65 \mathrm{Tg} \mathrm{S} \mathrm{yr}^{-1}$ from fuel combustion and industrial activities is taken from the GEIA database for 1985 [Benkovitz et al., 1996]. A small aircraft source is added on a latitude-altitude grid (G. McInnes, personal communication, 1991).

Oceanic DMS emission of $22 \mathrm{Tg} \mathrm{S} \mathrm{yr}^{-1}$ is computed as a product of sea-to-air transfer velocity and seawater DMS concentrations. We use the parameterization of Tans et al. [1990] (given by Erick- 

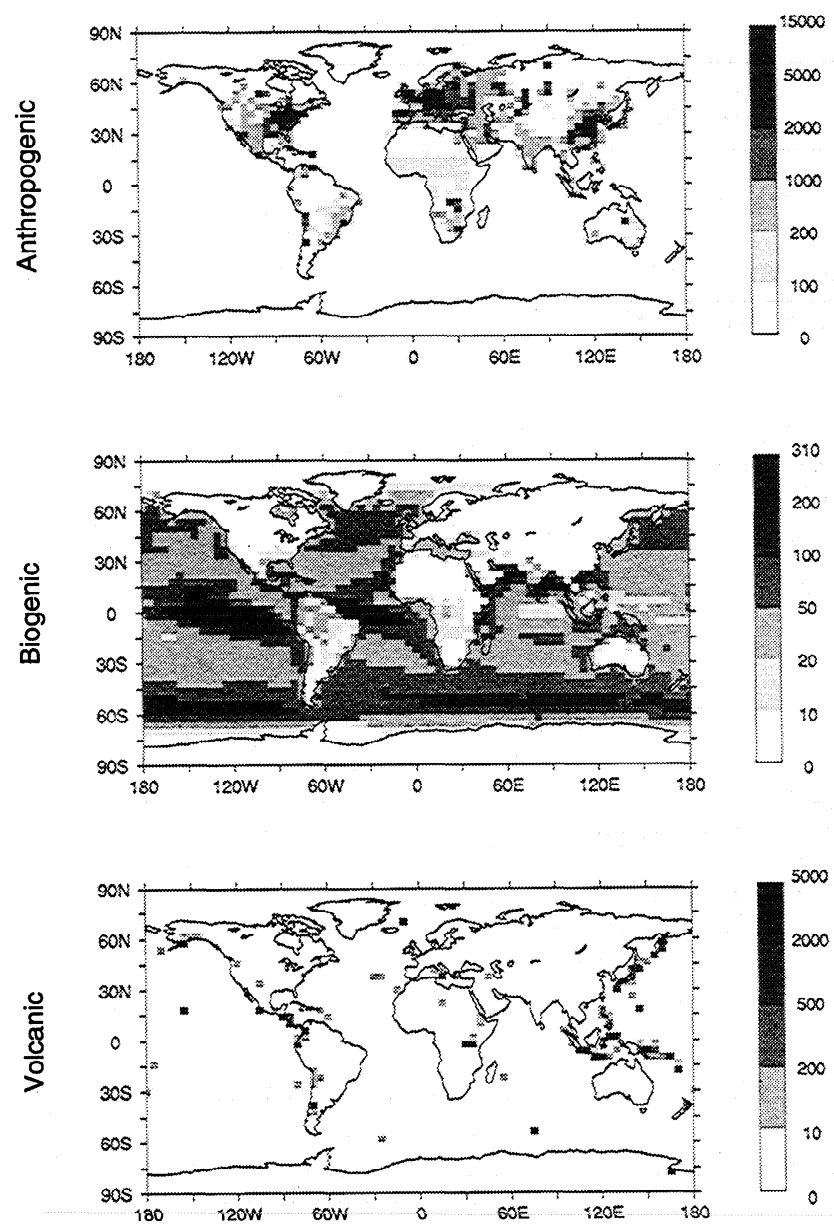

Figure 1. Annual emissions of sulfur from anthropogenic, biogenic, and volcanic sources (mg S m $\mathrm{m}^{-2} \mathrm{yr}^{-1}$ ) in the model. Anthropogenic sources include $\mathrm{SO}_{2}$ surface emissions from fossil fuel combustion for 1985 and biomass burning, and column integrated aircraft emission. Biogenic sources include surface emissions of DMS from the ocean, and DMS and $\mathrm{H}_{2} \mathrm{~S}$ from the terrestrial biosphere. Volcanic source includes column integrated $\mathrm{SO}_{2}$ emission for 1985 from both eruptive and noneruptive volcanoes (see text and Table 2 for details).

son [1993]) for the sea-to-air transfer velocity. The parameterization is dependent on the wind speed at $10 \mathrm{~m}$ altitude; this wind speed is inferred from the wind in the lowest GCM layer ( $250 \mathrm{~m}$ altitude) by assuming a logarithmic dependence of wind speed on altitude with roughness heights from Hicks and Liss [1976]. Seawater DMS concentration are specified following Bates et al. [1987] as a function of latitude, longitude (in the tropics), and season.

Sulfur sources from the terrestrial biosphere, biomass burning and noneruptive volcanoes are from Spiro et al. [1992]. Eruptive volcanic emissions of $\mathrm{SO}_{2}$ are for 1985 and are computed by applying the methodology of Spiro et al. [1992] to a chronology of volcanism from Simkin and Siebert [1994] for the year 1985 (see Table 2 for details). We obtain a total eruptive volcanic source of 4.0 $\mathrm{Tg} \mathrm{S} \mathrm{yr}^{-1}$ for 1985 , representing $4 \%$ of global sulfur emissions in Table 2. Spiro et al. [1992] previously reported a 9-year average value (1964-1972) of $5.1 \mathrm{Tg} \mathrm{S} \mathrm{yr}^{-1}$ for eruptive volcanic emissions; volcanic activity in 1985 was slightly weaker than normal.

The simulation does not account for primary $\mathrm{SO}_{4}{ }^{2-}$ emitted by soil dust, sea spray, or combustion. Soil dust makes little contribu- tion to $\mathrm{SO}_{4}{ }^{2-}$ even in dusty regions [Flocchini et al., 1981; Savoie et al., 1989a; Barrie and Barrie, 1990]. Sea spray is a major source of $\mathrm{SO}_{4}{ }^{2-}$ in marine surface air but it is customary to subtract its contribution in the observations and to report the residual as "nonsea-salt" $\mathrm{SO}_{4}{ }^{2-}$ [Keene et al., 1986]. Emission factors for combustion in the United States indicate that only $3 \%$ of total sulfur is emitted as $\mathrm{SO}_{4}{ }^{2-}$ [Environmental Protection Agency, 1989].

Annual sulfur emissions from anthropogenic, biogenic, and volcanic sources arc shown in Figurc 1. The most serious weakness in our present understanding of sulfur emissions is probably the oceanic source of DMS. Global estimates of this source range from 10 to $50 \mathrm{Tg} \mathrm{S} \mathrm{yr}^{-1}$ [Intergovernmental Panel on Climate Change, 1992], reflecting large uncertainties in both seawater DMS concentrations and sea-to-air transfer velocities. For example, different assumptions of relationships between wind speed and transfer velocity can result in factor of 2 differences in the calculated DMS flux from the ocean [Yvon et al., 1996]. Our global DMS source of $22 \mathrm{Tg} \mathrm{S} \mathrm{yr}^{-1}$ affords a good simulation of $\mathrm{SO}_{4}{ }^{2-}$ concentrations at remote oceanic sites. It leads, however, to an overestimate of DMS concentrations in the marine boundary layer unless a missing sink for DMS is assumed, as discussed below.

\section{Chemistry}

Chemical reactions included in the model are listed in Table 3. The concentrations of $\mathrm{OH}$ are taken from the CTM methylchloroform simulation of Spivakovsky et al. [1990] as three-dimensional fields of 5-day average quantities. The diel variations of $\mathrm{OH}$ concentrations are obtained by scaling the 5-day average values to the cosine of the solar zenith angle. Oxidation of DMS by $\mathrm{NO}_{3}$ at night is assumed to be limited by the rate of $\mathrm{NO}_{3}$ production from the $\mathrm{NO}_{2}+\mathrm{O}_{3}$ reaction; this assumption yields an upper limit, since other $\mathrm{NO}_{3}$ losses at night are not considered. The rates of $\mathrm{NO}_{3}$ production are computed using global fields of $\mathrm{NO}_{X}$ and $\mathrm{O}_{3}$ concentrations compiled by Spivakovsky et al. [1990]. We find that loss of DMS by reaction with $\mathrm{NO}_{3}$ amounts globally to $30 \%$ of loss by reaction with $\mathrm{OH}$, and effectively prevents DMS from accumulating at high latitudes in winter.

Using the DMS source calculated as described above, we find that the model reproduces the $\mathrm{SO}_{4}{ }^{2-}$ concentrations and wet deposition fluxes observed at remote marine sites but overestimates DMS concentrations in marine air by a factor of 2 on average. This discrepancy implies that the model overestimates the lifetime of DMS in the marine boundary layer. Several previous studies of the sulfur budget in the marine boundary layer have indicated that DMS is oxidized faster than would be expected from reaction with $\mathrm{OH}$ and $\mathrm{NO}_{3}$ [Nguyen et al., 1983; Barnes et al., 1989; Cooper and Saltzman, 1991; Jacob et al., 1995]; and the recent field studies by Suhre et al. [1995] and Yvon et al. [1996] in tropical marine air suggest that the DMS oxidation rate has to be doubled from the reaction with $\mathrm{OH}$ (as derived from a photochemical model) in order to explain the observed concentrations of DMS and its products. We assume here the presence of an oxidant $X$ which reacts with DMS as fast as $\mathrm{OH}$ and $\mathrm{NO}_{3}$ combined, so that the DMS lifetime is decreased uniformly by a factor of 2 (Table 3 ). The need for including this DMS $+X$ reaction in the model reflects either model underestimates of $\mathrm{OH}$ or $\mathrm{NO}_{3}$, or the actual presence in the atmosphere of other important DMS oxidants. It has been speculated that $\mathrm{Cl}$ and $\mathrm{BrO}$ might represent significant additional oxidants for DMS [Pszenny et al., 1993; Toumi, 1994] and aqueous phase oxidation by $\mathrm{O}_{3}$ in clouds could also be important [Lee and Zhou, 1994]. We assume that the DMS $+X$ reaction produces $\mathrm{SO}_{2}$ with $100 \%$ yield, as this assumption yields the best simulation of observed MSA to $\mathrm{SO}_{4}{ }^{2-}$ concentration ratios. 
Table 3. Chemical Mechanism in the Model

\begin{tabular}{|c|c|c|}
\hline Reaction & $\begin{array}{l}\text { Rate Coefficient, } \\
\mathrm{cm}^{3} \text { molecule }{ }^{-1} \mathrm{~s}^{-1}\end{array}$ & Note \\
\hline $\begin{array}{l}\mathrm{H}_{2} \mathrm{~S}+\mathrm{OH} \rightarrow \mathrm{SO}_{2}+\ldots \\
\mathrm{DMS}+\mathrm{OH} \rightarrow \mathrm{SO}_{2}+\ldots \\
(\mathrm{H} \text { abstraction) }\end{array}$ & $\begin{array}{l}6.3 \times 10^{-12} \exp (-80 / T) \\
9.6 \times 10^{-12} \exp (-234 / T)\end{array}$ & $\begin{array}{l}\mathrm{a} \\
\mathrm{b}\end{array}$ \\
\hline $\begin{array}{l}\mathrm{DMS}+\mathrm{OH} \rightarrow 0.75 \mathrm{SO}_{2}+0.25 \mathrm{MSA}+\ldots \\
(\mathrm{OH} \text { addition })\end{array}$ & $\frac{1.7 \times 10^{-42} \exp (7810 / T)\left[O_{2}\right]}{1+5.5 \times 10^{-31} \exp (7460 / T)\left[O_{2}\right]}$ & $b, c$ \\
\hline $\begin{array}{l}\mathrm{DMS}+\mathrm{NO}_{3} \rightarrow \mathrm{SO}_{2}+\ldots \\
\mathrm{DMS}+\mathrm{X} \rightarrow \mathrm{SO}_{2}+\ldots\end{array}$ & & $\begin{array}{l}\text { d } \\
\mathrm{e}\end{array}$ \\
\hline $\mathrm{SO}_{2}+\mathrm{OH}(\mathrm{g}) \rightarrow \mathrm{H}_{2} \mathrm{SO}_{4}+\ldots$ & $\begin{aligned}\left\{\frac{k_{0}(T)[M]}{1+k_{0}(T)[M] / k_{\infty}(T)}\right\} 0.6^{\left\{1+\left[\log \left(k_{0}(T)[M] / k_{\infty}(T)\right)\right]^{2}\right\}^{-1}} & \\
\text { with } k_{0} & =3.0 \times 10^{-31} \times(300 / T)^{3.3} \\
\text { and } k_{\infty} & =1.5 \times 10^{-12}\end{aligned}$ & $\mathbf{a}$ \\
\hline $\begin{array}{l}\mathrm{SO}_{2}+\mathrm{H}_{2} \mathrm{O}_{2}(\mathrm{aq}) \rightarrow \mathrm{H}_{2} \mathrm{SO}_{4}+\ldots \\
\mathrm{OCS}+h v, \mathrm{OH}, \mathrm{O} \rightarrow \mathrm{SO}_{2}+\ldots\end{array}$ & & $\begin{array}{l}\text { f } \\
\mathrm{g}\end{array}$ \\
\hline $\begin{array}{l}\text { a From DeMore et al. [1992]. } \\
\text { b From Atkinson et al. [1989]. } \\
\text { c Yields of } \mathrm{SO}_{2} \text { and MSA from Chatfie } \\
{ }^{d} \text { Assumed to be limited by the rate of } \\
\text { constant for the } \mathrm{NO}_{2}+\mathrm{O}_{3} \text { reaction is from } \\
{ }^{\mathrm{e}} \mathrm{X} \text { is an additional oxidant assumed to } \\
{ }^{\mathrm{f}} \text { Assumed to proceed to completion (ti }\end{array}$ & $\begin{array}{l}\text { and Crutzen [1990]. } \\
\mathrm{O}_{3} \text { formation at night from the } \mathrm{NO}_{2}+\mathrm{O}_{3} \text { reaction (see text). } \mathrm{T} \\
\text { DeMore et al. [1992]. } \\
\text { eact with DMS at the same rate as } \mathrm{OH} \text { and } \mathrm{NO}_{3} \text { combined. } \\
\text { ate the limiting reagent) in cloudy air over the 4-hour time step. } \\
\text { on of altitude from Chin and Davis }[1995] \text {. }\end{array}$ & rate \\
\hline
\end{tabular}

Aqueous phase oxidation of $\mathrm{SO}_{2}$ by $\mathrm{H}_{2} \mathrm{O}_{2}$ proceeds to completion in less than one hour in cloud [Daum et al., 1984] but is unimportant out of cloud. Cloud volume fractions for each grid box in the CTM are specified from the GCM meteorological archive (Table 1). Within these cloud volume fractions we assume that the reaction of $\mathrm{SO}_{2}$ with $\mathrm{H}_{2} \mathrm{O}_{2}$ titrates the limiting reagent over the course of the 4-hour model time step. The $\mathrm{H}_{2} \mathrm{O}_{2}$ concentration at the beginning of each time step is specified as a function of altitude, latitude and season (Figure 2) using the photochemical model of Spivakovsky et al. [1990]. For most of the world, $\mathrm{H}_{2} \mathrm{O}_{2}$ is in excess of $\mathrm{SO}_{2}$, except in polluted regions of northern middle and high latitudes.

\section{Deposition}

Wet deposition of $\mathrm{SO}_{4}{ }^{2-}$ and MSA aerosol is computed using the scavenging scheme developed by Balkanski et al. [1993] and previously tested by simulation of $210 \mathrm{~Pb}$ aerosol. This scheme accounts for efficient scavenging in wet convective updrafts (50\% in shallow convection and $100 \%$ in deep convection; see Table 1 for definition of shallow and deep). It also accounts for first-order losses by rainout and washout in large-scale (synoptic) precipita- tion. Most of the aerosol scavenging on a global scale in the model is in convective updrafts. Large-scale precipitation is important only at middle and high latitudes in winter. Following Davidson [1989], we assume that aerosol is not scavenged from ice clouds at temperatures below $258 \mathrm{~K}$ because of the absence of riming; this assumption limits the scavenging of sulfate over the Arctic in winter.

Because the solubility of $\mathrm{SO}_{2}$ in water is relatively low, scavenging of $\mathrm{SO}_{2}$ by precipitation is treated as contingent on rapid aqueous phase oxidation of $\mathrm{SO}_{2}$ by $\mathrm{H}_{2} \mathrm{O}_{2}$. We define a soluble fraction of $\mathrm{SO}_{2}$ as limited by the availability of $\mathrm{H}_{2} \mathrm{O}_{2}$ in the precipitating grid box, and we scavenge this soluble fraction in wet convective updrafts and by rainout in the same way as $\mathrm{SO}_{4}{ }^{2}$. Washout of the soluble fraction of $\mathrm{SO}_{2}$ by large-scale precipitation is assumed to be rapid relative to the 4-hour duration of the time step, based on calculations by Levine and Schwartz [1982] which indicate that highly soluble gases are scavenged from a rainy air column on a timescale of less than 1 hour.

Dry deposition of $\mathrm{SO}_{2}, \mathrm{SO}_{4}{ }^{2-}$, and MSA is modeled with the resistance-in-series scheme of Wesely and Hicks [1977] applied to the midpoint of the lowest model layer ( $250 \mathrm{~m}$ above the surface).

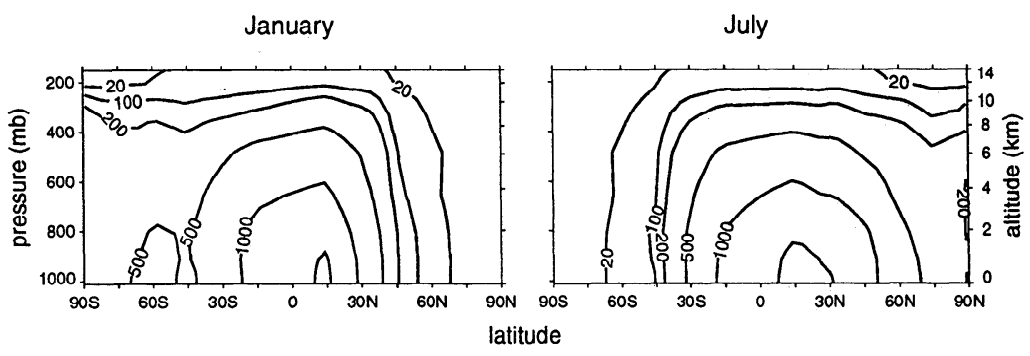

Contours: $20,100,200,500,1000,1500$

Figure 2. Concentrations of $\mathrm{H}_{2} \mathrm{O}_{2}$ (ppt) used in the model for January and July, as a function of altitude and latitude. 

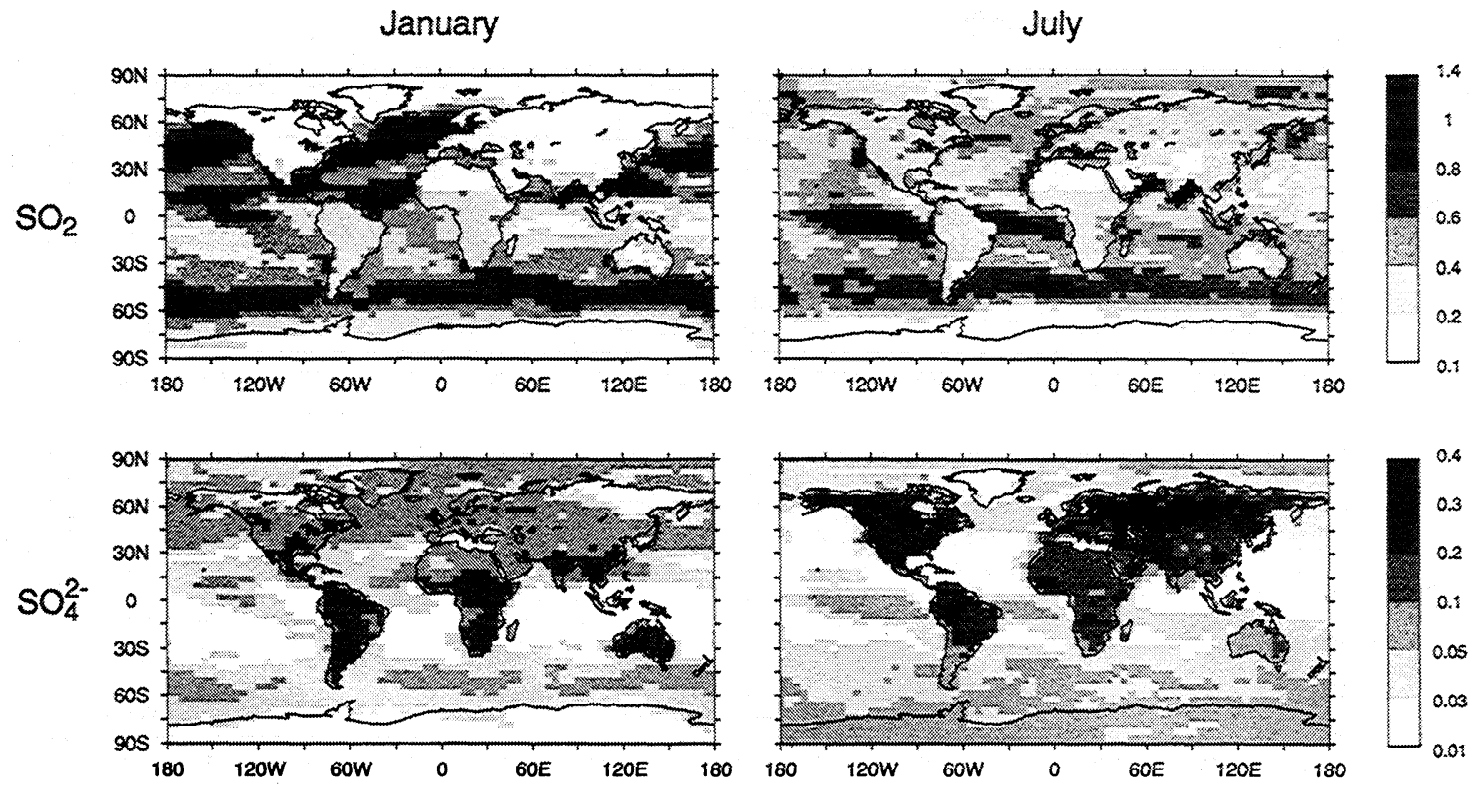

Figure 3. Mean $\mathrm{SO}_{2}$ and $\mathrm{SO}_{4}{ }^{2-}$ dry deposition velocities $\left(\mathrm{cm} \mathrm{s}^{-1}\right)$ at $250 \mathrm{~m}$ altitude computed in the model for January and July.

Aerodynamic resistances are parameterized as a function of local wind speed, solar radiation flux, cloud cover, and terrain [Jacob et al., 1993a]. The surface resistance of $\mathrm{SO}_{2}$ is parameterized following Wesely [1989] as a function of local surface type (specified with $1^{\circ} \times 1^{\circ}$ resolution from Matthews [1983]), temperature, and insolation. We assume a minimum $\mathrm{SO}_{2}$ dry deposition velocity of 0.1 $\mathrm{cm} \mathrm{s}^{-1}$ under stable nighttime conditions, and over ice and snow [Voldner et al., 1986]. The surface resistance of aerosol $\mathrm{SO}_{4}{ }^{2-}$ is parameterized as a function of local meteorological variables following Wesely et al. [1985] and Hicks et al. [1989], as described by Balkanski et al. [1993]. MSA is assumed to have the same dry deposition velocity as $\mathrm{SO}_{4}{ }^{2-}$.

Figure 3 shows the calculated January and July mean dry deposition velocities for $\mathrm{SO}_{2}$ and $\mathrm{SO}_{4}{ }^{2-}$. Dry deposition velocities for $\mathrm{SO}_{2}$ are $0.3-1.0 \mathrm{~cm} \mathrm{~s}^{-1}$ over the ocean and $0.1-0.5 \mathrm{~cm} \mathrm{~s}^{-1}$ over land. Dry deposition velocities for $\mathrm{SO}_{4}{ }^{2-}$ range from 0.01 to 0.4 $\mathrm{cm} \mathrm{s}^{-1}$, reflecting principally variations in surface roughness.

\section{Comparison With Observations}

Figure 4 shows the simulated concentrations of $\mathrm{DMS}, \mathrm{SO}_{2}$, $\mathrm{SO}_{4}{ }^{2-}$ and MSA for January and July in surface air (Figure 4a) and at $6 \mathrm{~km}$ altitude (Figure $4 \mathrm{~b}$ ). The annually averaged zonal mean concentration of $\mathrm{SO}_{4}{ }^{2-}$ as a function of altitude and latitude is shown in Figure 5. The GISS GCM is intended to simulate a typical meteorological year, rather than any specific year; model results are therefore best compared with long-term observational statistics. The principal diagnostics used in this paper are monthly mean concentrations at sites with at least one full year of observations. For North America and Europe, which have a high density of monitoring stations, we focus our attention on a small subset of nonurban sites where we expect concentrations to be determined more by regional-scale pollution than by local influences. Aircraft provide the only source of data in the free troposphere and we therefore use these data for model evaluation, even though they are of limited temporal extent; we aggregate them regionally to improve statistics. The same approach is used for ship cruises, which provide the largest source of data for $\mathrm{DMS}$ and $\mathrm{SO}_{2}$ concen- trations in marine air. All observations presented in this paper were collected between 1978 and 1993, so that our use of an anthropogenic emission inventory for 1985 should be appropriate. Eruptive volcanic emissions for 1985 are included in the simulation shown in Figure 4 and in the budget analysis of section 4 but are excluded from the simulation used for comparison with observations, as the distribution of volcanic eruptions varies greatly from year to year.

\section{Dimethyl Sulfide}

Simulated DMS concentrations in marine air are compared in Table 4 to observations. If $\mathrm{OH}$ and $\mathrm{NO}_{3}$ were the only DMS oxidants in the model, the observations would be overestimated by a factor of 2 on average. By invoking an additional oxidant to decrease the DMS lifetime by a factor of 2 (Table 3), we avoid systematic global bias. Thus the median simulated-to-observed concentration ratio in Table 4 is 1.1 (quartiles are 0.5 and 2.0). There is also no latitude-dependent bias, as shown in Figure 6. The model docs not capture the large spatial variance in the observations, which is not driven by latitude (the observations are mainly from the growing season) but rather appears to reflect small-scale variations in wind speed and seawater DMS concentrations. The model features particularly high DMS concentrations at $60^{\circ} \mathrm{S}$ in summer (Figure 4) because of a combination of high wind speeds and high DMS seawater concentrations in the Southern Occan. There is also some small-scale variance in the model driven by wind speed, as shown in Figure 6 by the spike for the eastern equatorial Pacific; this variance would not be expected to correlate with the observations in view of the climatological nature of the model and the short temporal extent of the observations.

We compare in Figure 7 the simulated and observed seasonal variations of DMS concentrations at the two sites where long-term observations are available: Amsterdam Island (Indian Ocean) and Cape Grim (Tasmania). The model reproduces closely the amplitude and phase of the seasonal cycles, which are determined largely by the cycles of seawater DMS concentrations.

Vertical profiles of DMS in the model are compared in Figure 8 to aircraft observations; two of these observations are over the 

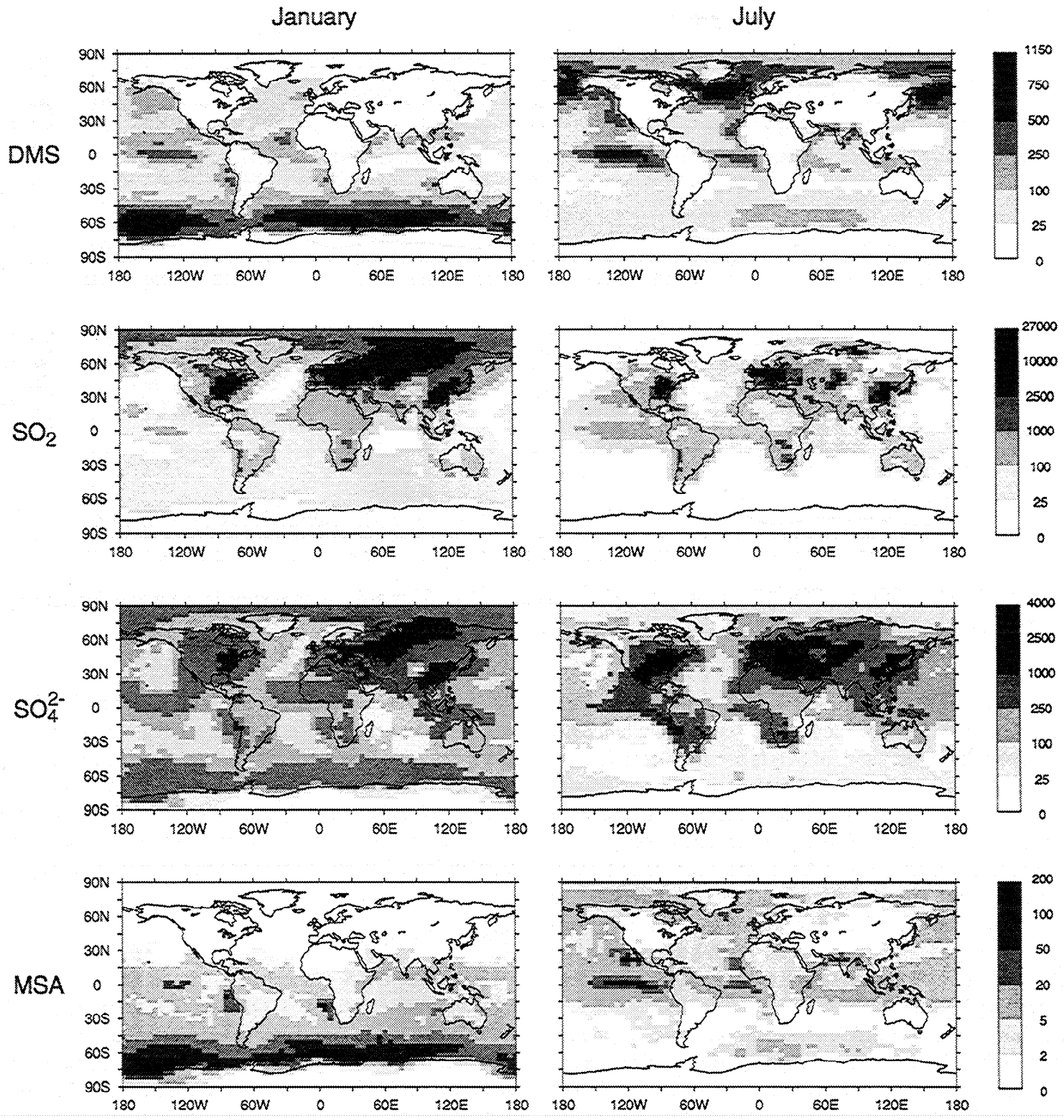

Figure 4a. Simulated concentrations (ppt) of DMS, $\mathrm{SO}_{2}, \mathrm{SO}_{4}{ }^{2-}$, and MSA in surface air for January and July.

Amazon and Congo rainforest, where DMS originates from terrestrial vegetation [Andreae et al., 1990a; Bingemer et al., 1992]. In general, both model and observations indicate a rapid decline of concentrations above the boundary layer, as would be expected from the short lifetime of DMS (averaging 1.0 days in the model). The observations over the tropical Pacific show frequent enhancements of DMS in the upper troposphere because of decp convection; the model underestimates these enhancements, not because of insufficient convection but rather because of insufficient DMS in surface air in the flight regions. The model tends to underestimate midtropospheric $(2-6 \mathrm{~km})$ concentrations throughout the tropics, probably because of the nondetraining nature of convection in the GISS GCM. The model overestimates by more than a factor of 3 the low-altitude aircraft observations by Berresheim et al. [1990] at Cape Grim in December. However, as previously shown in Figure 7, the model reproduces closely the surface observations at that site. Berresheim et al. [1990] suggest that they may have flown during a period of anomalously low DMS emission.

\section{Sulfur Dioxide}

Model results for $\mathrm{SO}_{2}$ are compared in Table 5 to observations from a number of locations around the world. Seasonal variations are shown in Figure 9 for sites with at least 1 year of observations. Dashed lines in the figure show the natural component of $\mathrm{SO}_{2}$ obtained in a simulation with no emissions from fossil fuel combustion or industrial activities. Dotted lines show results from a simulation without $\mathrm{H}_{2} \mathrm{O}_{2}$ limitation of in-cloud $\mathrm{SO}_{2}$ oxidation, i.e., assuming that in-cloud oxidation of $\mathrm{SO}_{2}$ is limited solely by the frequency of passage of air through cloud. These sensitivity simulations were conducted following the same protocol as the standard simulation, i.e., for a 15 -month period with the first 3 months used for initialization.

The model reproduces the observed $\mathrm{SO}_{2}$ concentrations over the United States and Europe, where emissions from fossil fuel combustion and industrial activities are high. Annual mean $\mathrm{SO}_{2}$ concentrations in the model are within $30 \%$ of observed values at sites A-F of Table 5. The observed seasonal cycle, with wintertime 

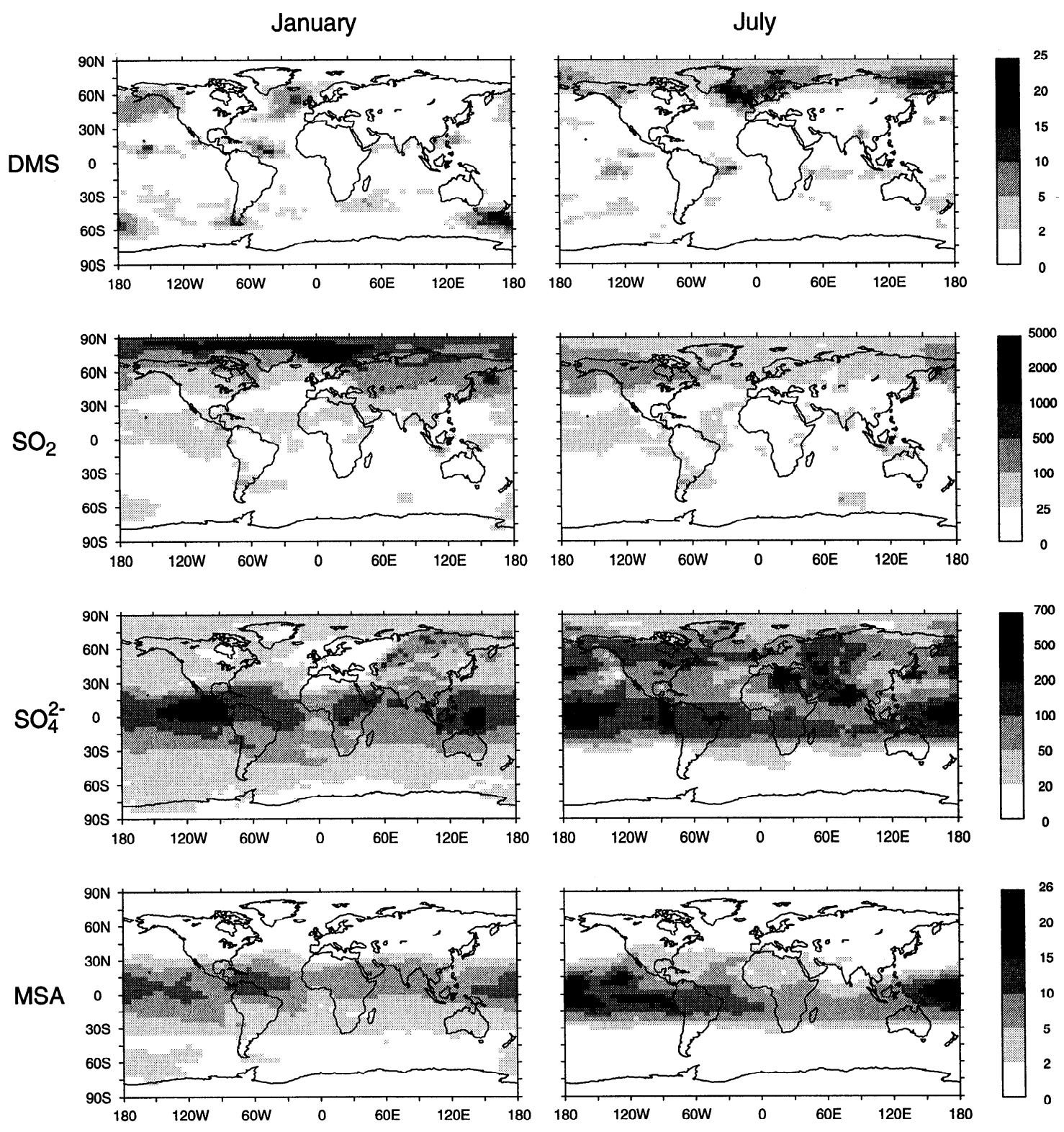

Figure 4b. Simulated concentrations (ppt) of DMS, $\mathrm{SO}_{2}, \mathrm{SO}_{4}{ }^{2-}$, and MSA at $6 \mathrm{~km}$ altitude for January and July.

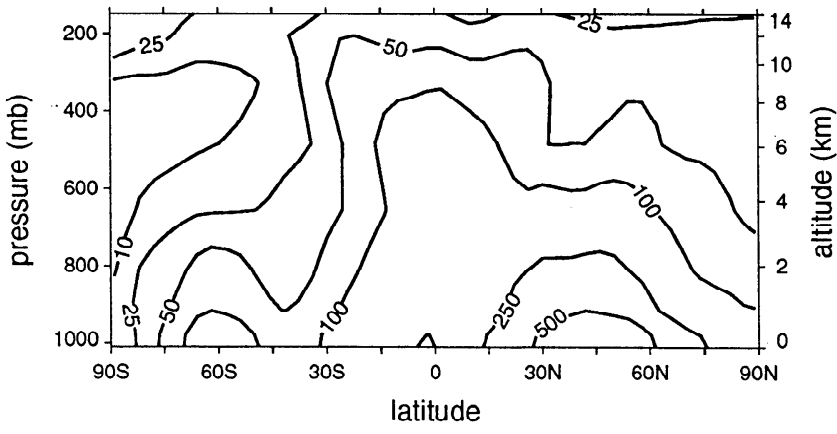

Contours: $10,20,50,100,200,500$

Figure 5. Simulated zonal mean, annually averaged concentrations of $\mathrm{SO}_{4}{ }^{2-}(\mathrm{ppt})$ as a function of altitude and latitude. concentrations about a factor of 2 higher than in summer, is also captured by the model. The simulation of $\mathrm{SO}_{2}$ in the model is strongly dependent on the limitation of $\mathrm{SO}_{2}$ oxidation by the availability of $\mathrm{H}_{2} \mathrm{O}_{2}$; as shown in Figure 9, without this limitation we would underestimate $\mathrm{SO}_{2}$ concentrations throughout the year, and the observed seasonality of $\mathrm{SO}_{2}$ would not he reproduced. The previous models of Langner and Rodhe [1991] and Pham et al. [1995], which did not include the $\mathrm{H}_{2} \mathrm{O}_{2}$ limitation, show a large undercstimate of $\mathrm{SO}_{2}$ concentrations over the eastern United States and do not capture the seasonal variations. However, Pham et al. [1995] tend to overestimate $\mathrm{SO}_{2}$ concentrations over Europe in both summer and winter. Frequency of processing of air by cloud is another important variable affecting conversion of $\mathrm{SO}_{2}$ to $\mathrm{SO}_{4}{ }^{2-}$ and is not easily evaluated with observations.

Figure 9 includes data from a number of Arctic sites in Europe and North America (sites G-K). Although the model captures qualitatively the winter maxima caused by transport of pollution 
Table 4. Observed and Simulated DMS Concentrations in Marine Surface Air

\begin{tabular}{|c|c|c|c|c|}
\hline \multirow[b]{2}{*}{ Site } & \multirow[b]{2}{*}{ Period } & \multicolumn{2}{|c|}{$\mathrm{DMS}^{\mathrm{a}}, \mathrm{ppt}$} & \multirow[b]{2}{*}{ Referenceb } \\
\hline & & Observed & Model & \\
\hline A. Amsterdam Island & $\begin{array}{l}\text { Jan. } 1984 \text { - Aug. 1984; } \\
\text { March } 1987 \text { - Dec. } 1990\end{array}$ & 112 & 106 & NG \\
\hline B. Cape Grim & Nov. 1988 - May 1990 & 67 & 73 & $\mathrm{AY}$ \\
\hline C. Bahamas & June 1985 & 154 & 40 & $\mathrm{SC}$ \\
\hline D. Gulf of Mexico & October 1985 & 25 & 41 & SC \\
\hline E. Caribbean Transect & Feb. - March 1985 & 83 & 60 & $\mathrm{SC}$ \\
\hline F. Bahamas & Nov. 1983 & 96 & 36 & AN \\
\hline G. N. Atlantic & April - May 1984 & 73 & 89 & AN \\
\hline H. Sargasso Sea & June 1984 & 180 & 78 & AN \\
\hline I. Atlantic Ocean, $32^{\circ} \mathrm{S}-10^{\circ} \mathrm{S}$ & March - April 1987 & 18 & 32 & BU \\
\hline $10^{\circ} \mathrm{S}-10^{\circ} \mathrm{N}$ & March - April 1987 & 37 & 97 & BU \\
\hline $10^{\circ} \mathrm{N}-30^{\circ} \mathrm{N}$ & March - April 1987 & 22 & 157 & BU \\
\hline $30^{\circ} \mathrm{N}-47^{\circ} \mathrm{N}$ & March - April 1987 & 11 & 43 & BU \\
\hline M. Tropical South Pacific & March 3-9, 1991 & 430 & 47 & YS \\
\hline N. Equatorial Pacific & Feb. - March 1991 & 352 & 181 & HU \\
\hline O. Equatorial Pacific & July 1982 & 125 & 508 & AN \\
\hline P. N. E. Pacific Coast & April 16-30, 1991 & 75 & 33 & BN \\
\hline Q. N. E. Pacific Coast & May $14-21,1987$ & 74 & 84 & BT \\
\hline R. Pacific Ocean, $15^{\circ} \mathrm{N}-29^{\circ} \mathrm{N}$ & April 6-May 5, 1988 & 62 & 51 & QU \\
\hline $14^{\circ} \mathrm{N}-11^{\circ} \mathrm{S}$ & April 6-May 5, 1988 & 278 & 115 & QU \\
\hline T. Cape Grim & Jan. 1984 & 126 & 154 & AN \\
\hline U. Subantarctic/Antarctic & March - April 1986 & 100 & 377 & $\mathrm{BE}$ \\
\hline V. Antarctic region, Drake Passage & Nov. - Dec. 1990 & 147 & 191 & SG \\
\hline W. Weddell Sea & Nov. - Dec. 1990 & 24 & 235 & SG \\
\hline to Cape Town & Nov. - Dec. 1990 & 671 & 667 & SG \\
\hline
\end{tabular}

a Mean DMS concentrations from the observations are averaged over the observation period, and from the model are the average values for the corresponding month(s) of the observation.

${ }^{b}$ References are AN, Andreae et al. [1985]; AY, Ayers et al. [1991]; BE, Berresheim [1987]; BN, Bandy et al. [1992]; BT, Bates et al. [1990]; BU, Bürgermeister et al. [1990]; HU, Huebert et al. [1993]; NG, Nguyen et al. [1992]; QU, Quinn et al. [1990]; SC, Saltzman and Cooper [1988]; SG, Staubes and Georgii [1993]; YS, Yvon and Saltzman [1996].

from Eurasia [Barrie, 1986], it tends to overestimate these maxima, particularly at Spitzbergen and Bear Island (sites $\mathbf{G}$ and $\mathrm{H}$ ). The sharp decrease of winter $\mathrm{SO}_{2}$ concentrations from Jergul (site I) to Bear Island in the observations has been attributed to rapid deposition of $\mathrm{SO}_{2}$ to the open ocean along the transport path [Barrie and Hoff, 1984]; however the model shows little dry deposition over that region (Figure 3) because sea ice in the GCM winter extends to the northern coast of Norway. It must be noted that the wintertime Arctic atmosphere is strongly stratified, and observations made at the surface would be particularly sensitive to $\mathrm{SO}_{2}$ deposition from a shallow surface layer not resolved by our model.

The only long-term record of $\mathrm{SO}_{2}$ observations in marine air is from Amsterdam Island (site $\mathrm{L}$ ). The model reproduces the

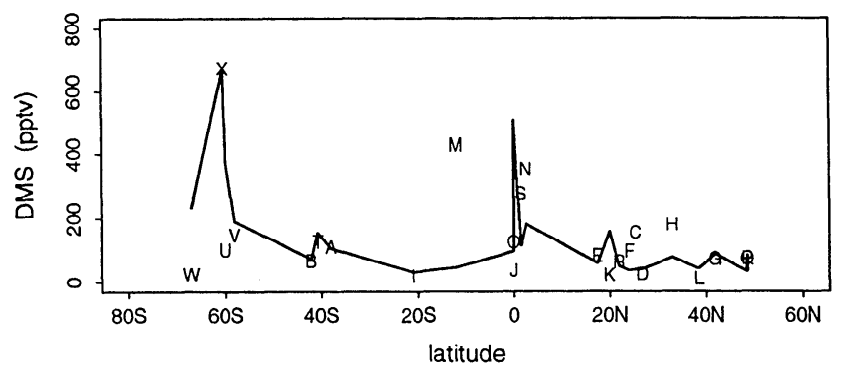

Figure 6. Latitudinal variation of observed (letters) and simulated (lines) DMS concentrations over the oceans. The letters correspond to the site locations in Table 4 (note that concentrations at site $\mathrm{P}$ and $\mathrm{Q}$ are overlapping). Model results are monthly means corresponding to the locations and periods of the observations. observed concentrations and their seasonal variation. The $\mathrm{SO}_{2}$ at Amsterdam Island originates mainly from DMS oxidation. Shorter-term observations of $\mathrm{SO}_{2}$ in marine air from ship cruises (Table 5) are also well simulated; the median simulated-toobserved concentration ratio for these data is 0.8 (quartiles are 0.4 and 1.2).

Vertical profiles of $\mathrm{SO}_{2}$ concentrations in marine air measured from aircraft are compared to model results in Figure 10. The high $\mathrm{SO}_{2}$ concentrations in the boundary layer over the northwest Atlantic, both in the model and in the observations, are due to advection of anthropogenic pollution from North America. Concentrations over the South Atlantic are much lower, both in the model and in the observations, and there is evidence that $\mathrm{SO}_{2}$ increases with altitude, reflecting at least in the model the pumping of DMS to the upper troposphere followed by oxidation to $\mathrm{SO}_{2}$ [Chatfield and Crutzen, 1984]. Simulated $\mathrm{SO}_{2}$ concentrations in the free troposphere over the North Pacific underestimate considerably observations made during the Pacific Exploratory Mission (PEM) West(A) expedition in October 1991, but these observations were heavily affected by the eruption of Mount Pinatubo [Thornton et al., 1996].

\section{Sulfate}

Long-term records of $\mathrm{SO}_{4}{ }^{2-}$ concentrations are available from many sites around the world (Table 6). Simulated and observed seasonal variations of concentrations for representative sites are compared in Figure 11. The model reproduces generally to within $20 \%$ the observed yearly mean $\mathrm{SO}_{4}{ }^{2-}$ concentrations observed at sites in the United States and Europe. Both model and observa- 

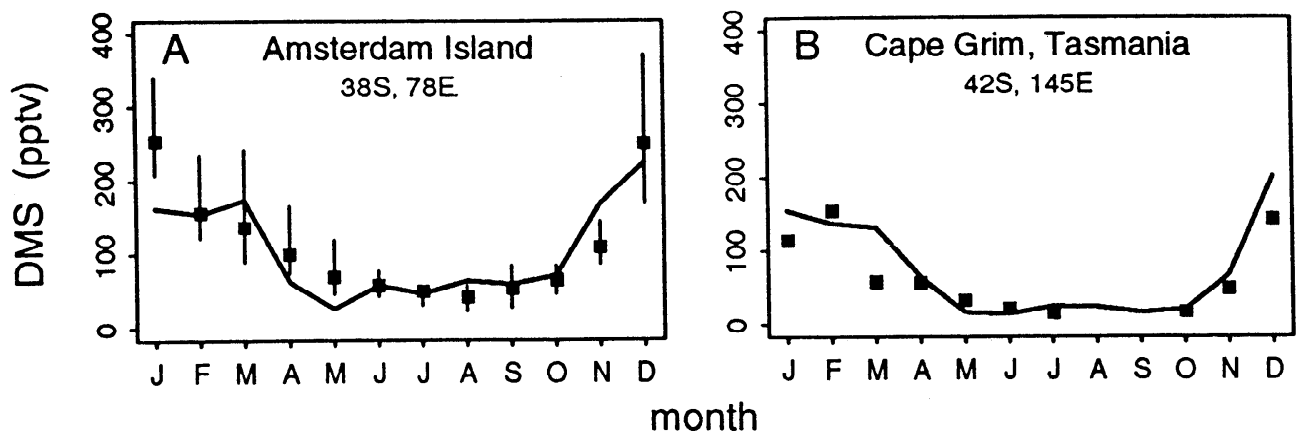

Figure 7. Seasonal variations of observed (squares) and simulated (lines) monthly mean DMS concentrations at Amsterdam Island [Nguyen et al., 1992] and Cape Grim [Ayers et al., 1991]. Vertical lines for Amsterdam Island indicate the 4-ycar interannual range of observed monthly means.
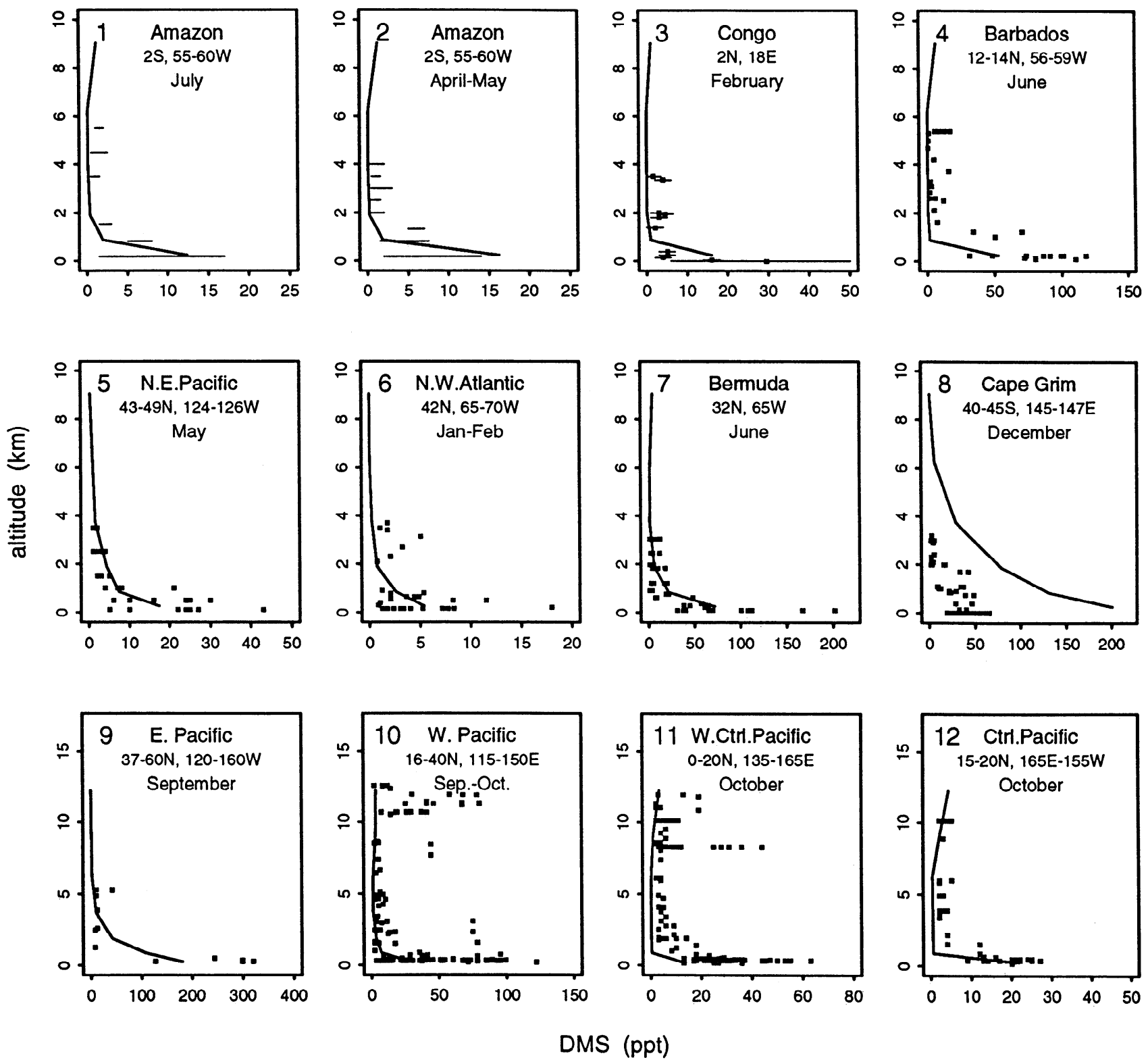

DMS (ppt)

Figure 8. Vertical profiles of DMS. Observations are shown as squares except in the first two panels, where the range of observations is given by the horizontal lines. The model mean concentrations for the corresponding locations and months are shown as lines. The observation periods and references are 1 and 2, July 1985 and April - May 1987, respectively [Andreae et al., 1990a]; 3, February 12-25, 1988 [Bingemer et al., 1992]; 4, June 18-27, 1984 [Ferek et al., 1986]; 5, May 3-12, 1985 [Andreae et al., 1988]; 6, January 4-7 and February 6-20, 1986 [Van Valin et al., 1987]; 7, June 8-16, 1986 [Luria et al., 1989]; 8, December 3-18, 1986 [Berresheim et al., 1990]; 9 to 12, September 16, September 22 to October 6, October 8-18, October 18-20, 1991, respectively (NASA Langley Research Center, PEM-West A data archive). 
Table 5. Observed and Simulated $\mathrm{SO}_{2}$ Concentrations in Surface Air

\begin{tabular}{|c|c|c|c|c|}
\hline \multirow{2}{*}{ Site } & \multirow{2}{*}{ Period } & \multicolumn{2}{|c|}{$\mathrm{SO}_{2}^{\mathrm{a}}, \mathrm{ppt}$} & \multirow{2}{*}{ Reference $^{b}$} \\
\hline & & Observed & Model & \\
\hline \multicolumn{5}{|c|}{ Industrial Region } \\
\hline A. Langenbrugge, Germany & 1986-1992 & 4880 & 6490 & EMEP \\
\hline B. Illmitz, Austria. & $1986-1992$ & 8030 & 7390 & EMEP \\
\hline C. Ispra, Italy & 1986-1992 & 3480 & 5470 & EMEP \\
\hline D. Ohio, U.S. & May 1980 - Aug. 1981 & 7980 & 7270 & SP \\
\hline E. Indiana, U.S. & May 1980 - Aug. 1981 & 8530 & 9700 & SP \\
\hline F. Kentucky, U.S. & May 1980 - Aug. 1981 & 7520 & 7860 & SP \\
\hline \multicolumn{5}{|c|}{ Arctic and Subarctic } \\
\hline G. Spitzbergen, Norway & 1986-1992 & 157 & 498 & EMEP \\
\hline H. Bear Island, Norway & Oct. 1978 - Sept. 1981 & 205 & 508 & HL \\
\hline I. Jergul, Norway & 1986-1992 & 700 & 805 & EMEP \\
\hline J. Janiskoski, Russia & 1986-1992 & 900 & 1050 & EMEP \\
\hline K. Cree Lake, Canada & $1982-1988$ & 242 & 350 & BB \\
\hline \multicolumn{5}{|c|}{ Ocean } \\
\hline L. Amsterdam Island & Mar. 1989 - Jan. 1991 & 19 & 21 & NG \\
\hline M. N. E. Atlantic Coast & July $22-30,1981$ & 70 & 63 & $\mathrm{HJ}$ \\
\hline N. N. Atlantic, W. of Europe & Aug. 1988 & 40 & 39 & PS \\
\hline W. of Africa & Aug. 1988 & 83 & 31 & PS \\
\hline N. of South America & Sept. 1988 & 35 & 40 & PS \\
\hline Q. Tropical South Pacific & March 3-9, 1991 & 71 & 28 & YS \\
\hline R. Equatorial Pacific & Feb. - March 1991 & 28 & 66 & HU \\
\hline S. N.E. Pacific Coast & April 16-30, 1991 & 28 & 21 & $\mathrm{BN}$ \\
\hline T. N. E. Pacific Coast & May $14-21,1987$ & 135 & 58 & BT \\
\hline U. Pacific Ocean, $30^{\circ} \mathrm{N}-50^{\circ} \mathrm{N}$ & April 6 - May 5, 1988 & 15 & 7 & QU \\
\hline $15^{\circ} \mathrm{N}-29^{\circ} \mathrm{N}$ & April 6 - May 5, 1988 & 85 & 26 & QU \\
\hline $14^{\circ} \mathrm{N}-11^{\circ} \mathrm{S}$ & April 6-May 5, 1988 & 30 & 53 & QU \\
\hline X. Subantarctic/Antarctic & March - April 1986 & 11 & 13 & $\mathrm{BE}$ \\
\hline
\end{tabular}

\footnotetext{
${ }^{a}$ For sites $\mathrm{A}-\mathrm{L}$, values are annual means. For sites $\mathrm{M}-\mathrm{X}$, mean $\mathrm{SO}_{2}$ concentrations from the observations are averaged over the observation period, and from the model are the average values for the corresponding month(s) of the observation.

${ }^{\mathrm{b}}$ References are BB, Barrie and Bottenheim [1990]; BE, Berresheim [1987]; BN, Bandy et al. [1992]; BT, Bates ct al. [1990]; EMEP, Norwegian Institute for Air Research [1988-1994]; HJ, Herrmann and Jaeschke [1984]; HL, Heintzenberg and Larssen [1983]; HU, Huebert et al. [1993]; NG, Nguyen et al., [1992]; PS, Pszenny et al., [1990]; QU, Quinn et al., [1990]; SP, Shaw and Paur [1983]; YS, Yvon and Saltzman [1996].
}

tions show a summer maximum over the eastern United States (Figure 11a). By contrast, ${ }^{210} \mathrm{~Pb}$ aerosol over the United Statcs shows a winter maximum, reflecting the seasonal variation of boundary layer mixing [Balkanski et al., 1993]. Oxidation of $\mathrm{SO}_{2}$ to $\mathrm{SO}_{4}{ }^{2-}$ is slower in winter than in summer because of low $\mathrm{OH}$ and $\mathrm{H}_{2} \mathrm{O}_{2}$ concentrations, more than compensating for the seasonal variation in boundary layer mixing. If we did not account in the model for the limitation of in-cloud $\mathrm{SO}_{2}$ oxidation by the $\mathrm{H}_{2} \mathrm{O}_{2}$ supply, $\mathrm{SO}_{4}{ }^{2-}$ concentrations would be greatly overestimated and would peak in winter (dotted lines).

The model tends to underestinate wintertime $\mathrm{SO}_{4}{ }^{2-}$ concentrations over Europe (Figure 11a). One possiblc cxplanation is that anthropogenic $\mathrm{SO}_{2}$ emissions in Europe peak in winter [Semb, 1977], while the model assumes that these emissions remain constant throughout the year. However, the model reproduces the observed wintertime maximum of $\mathrm{SO}_{2}$ over Europe (Figure 9) cven without allowing for seasonal variation of $\mathrm{SO}_{2}$ emission. Another possibility is that direct anthropogenic emission of $\mathrm{SO}_{4}{ }^{2-}$ is not considered in the model; although this source is small compared to $\mathrm{SO}_{2}$ emission, it could be nonnegligible when the oxidation rate of $\mathrm{SO}_{2}$ is slow, such as in European winter.

Measurements at arctic and subarctic sitcs (Figurc 11b) often show a pronounced seasonal variation of $\mathrm{SO}_{4}{ }^{2-}$ concentrations, with maxima in late winter due to strong transport from the Eur- asian continent [Barrie and Bottenheim, 1990], and summertime minima comparable to observations in remote marine air. The model captures the observed low summer values but underestimates the winter maxima, particularly in the North American Arctic. Comparison of low-level wind patterns in the GCM and in climatological observations indicates that the transport from Eurasia to the North American Arctic in the GCM winter is too weak. In addition, wintertime precipitation over the Arctic is excessive in the GISS GCM [Hansen et al., 1983]. The model overestimates observations at Cree Lake in the Canadian subarctic because of excessive transport of North American pollution to that site.

Observations at marine sites in the northern hemisphere indicate strong seasonal anthropogenic enhancements of $\mathrm{SO}_{4}{ }^{2-}$ concentrations [Andreae et al., 1988; Savoie and Prospero, 1989; Savoie et al., 1989a] which are not captured by the model (Figure 11c). This problem appears to be caused by excessive scavenging of soluble tracers downwind of the northern midlatitude continents, as previously noted by Balkanski et al. [1993] in their simulation of ${ }^{210} \mathrm{~Pb}$. Precipitation anomalies in the GCM seem to be responsible. Transport of anthropogenic $\mathrm{SO}_{4}{ }^{2-}$ from North America to Bermuda in the GCM summer is also suppressed by a northeastward shift of the Bermuda High from its climatological location [Jacob and Prather, 1990]. Better agreement is found between model and observations in the central and South Pacific, where $\mathrm{SO}_{4}{ }^{2-}$ is prin- 

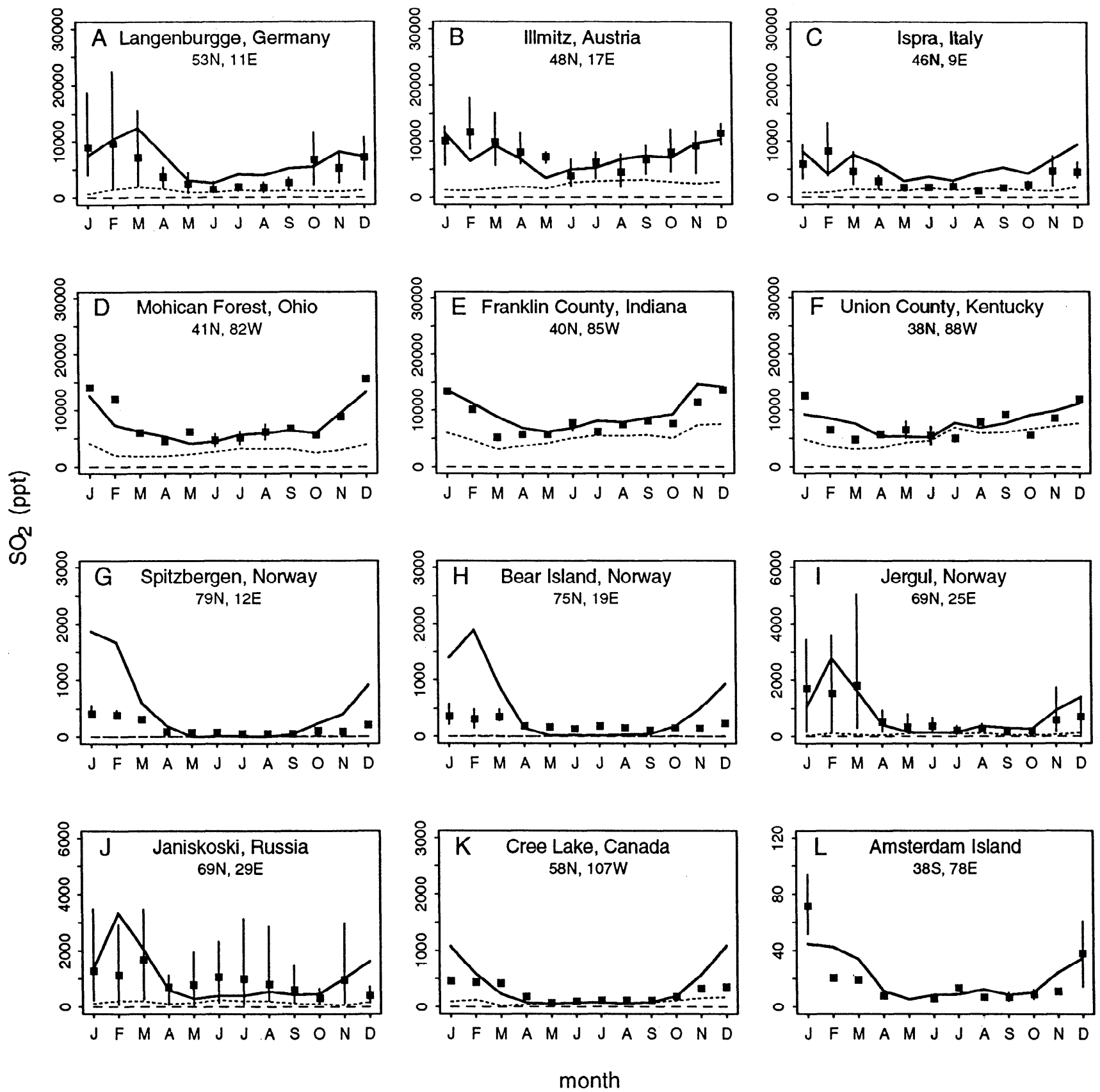

Figure 9. Seasonal variations of observed (squares) and simulated (lines) monthly mean $\mathrm{SO}_{2}$ concentrations in Europe, the United States, the Arctic, and Amsterdam Island. The interannual range of observed mcans is shown for sites with more than one year of data. References for the observations are given in Table 5 . Dashed lines are from a simulation without anthropogenic emissions. Dotted lines are from a simulation including no $\mathrm{H}_{2} \mathrm{O}_{2}$ limitation of incloud $\mathrm{SO}_{2}$ oxidation. In some panels the lines coincide.

cipally of biogenic origin. Summertime observations at the Antarctic coastal sites (Palmer, Mawson) are overestimated, which will be discussed further below in the context of results for MSA.

Simulated $\mathrm{SO}_{4}{ }^{2-}$ concentrations at altitude are compared to aircraft observations in Figure 12. The model captures the sharp decrease between the boundary layer and the free troposphere observed over eastern Canada in summer; however, as discussed earlier, it does not capture the anthropogenic enhancements observed over Bermuda and over the northern Pacific in spring. Midtroposphere concentrations over the Amazon Basin are greatly overestimated, reflecting long-range transport of marine-derived
$\mathrm{SO}_{4}{ }^{2-}$ over Brazil in the model; in the observations this marine component appears to be efficiently scavenged [Andreae et al., 1990a; Talbot et al., 1990]. A possible explanation for the insufficient scavenging in the model midtroposphere is that wet convection over tropical continents in the GISS GCM is nonentraining and is excessively dominated by deep events extending to near the tropopause [Del Genio and Yao, 1988]. Observations and modeling of cloud structure over the Amazon Basin [Scala et al., 1990] show that convective events extend over a full range of depths and include varying degrees of entrainment, which would enhance scavenging of $\mathrm{SO}_{2}$ and $\mathrm{SO}_{4}{ }^{2-}$ at midlevels. The model 

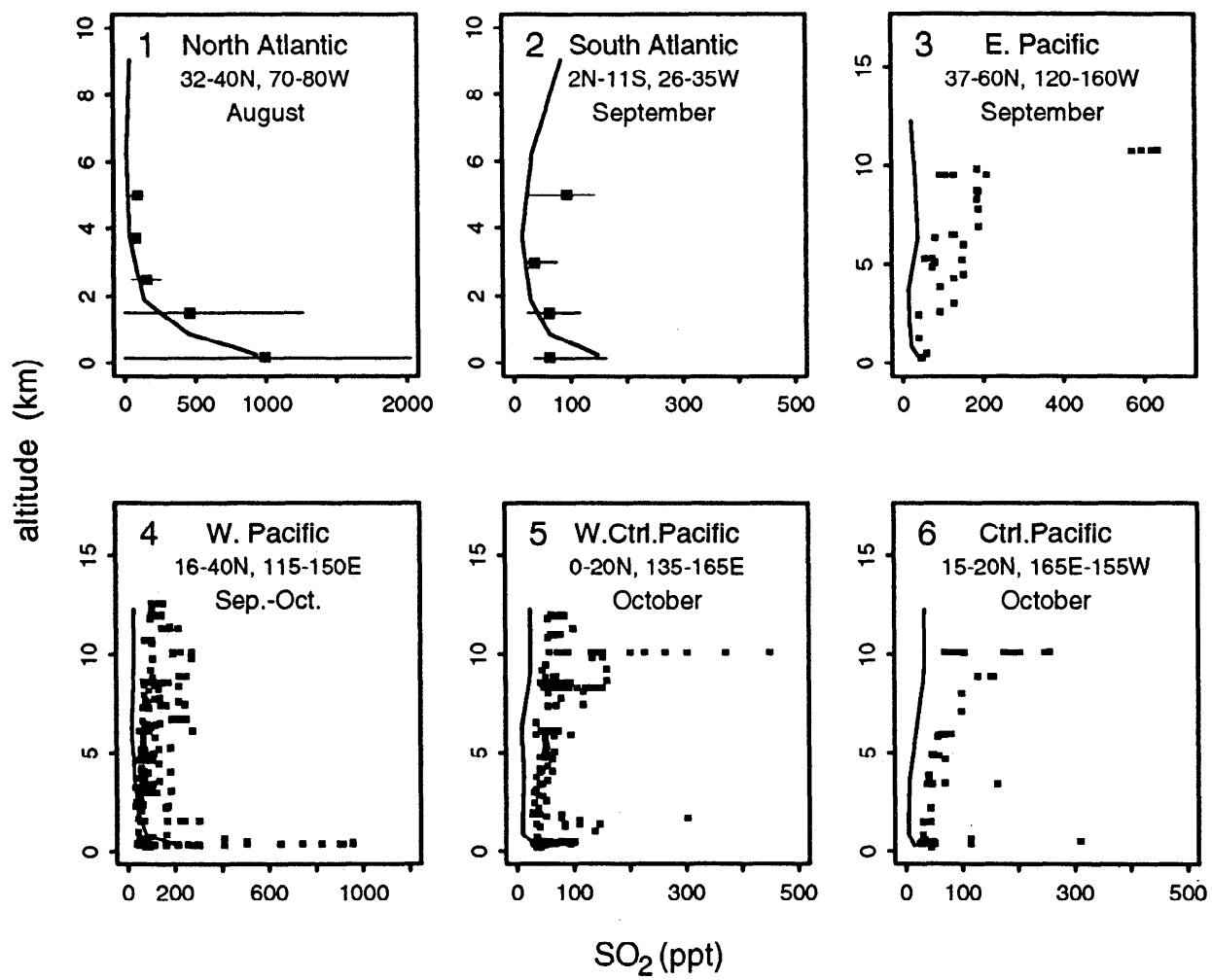

Figure 10. Vertical profiles of $\mathrm{SO}_{2}$ in marine air. The squares are observations, and the lines are model means for the corresponding locations and months. The observation periods and references are 1 and 2, August 22-30 and September 12-22, 1989, respectively [Thornton et al., 1993]; 3 to 6, September 16, September 22 to October 6, October 8-18, October 18-20, 1991, respectively (NASA Langley Research Center, PEM-West A data archive).

captures the observed decrease of $\mathrm{SO}_{4}{ }^{2-}$ concentrations with altitude over the North Pacific during the PEM-West (A) mission, although we saw previously that observed $\mathrm{SO}_{2}$ was much higher than simulated due to the influence of the Pinatubo eruption. The model overestimates the low-altitude aircraft observations of Berresheim et al. [1990] over Cape Grim, consistent with the underestimate of DMS in these same observations. As discussed above, however, the model captures well the observed DMS and $\mathrm{SO}_{4}^{2-}$ concentrations in surface air at the site.

Wet deposition fluxes of $\mathrm{SO}_{4}{ }^{2-}$ computed by the model are compared to observations in Table 7. For the United States and Europe, where the observational network is dense, we limit our attention to regional averages to remove the effect of small-scale spatial variability in precipitation. The model reproduces the observed deposition fluxes over the continents to within $15 \%$; more than $90 \%$ of this $\mathrm{SO}_{4}^{2-}$ is anthropogenic. Over oceans the scatter between model and observations is greater but the agreement is still within a factor of 2 , with no systematic global bias. These comparisons lend support to the overall magnitude of anthropogenic and oceanic sources of sulfur in the model.

\section{Methanesulfonic Acid}

Methanesulfonic acid is produced by the addition branch of the $\mathrm{DMS}+\mathrm{OH}$ reaction. Long-term observations of MSA are available from a number of marine sites (Table 8). Figure 13 compares the seasonal variations of MSA concentrations in the model with the observations at the sites of Table 8.

The seasonal variation of MSA is expected to largely follow that of DMS. The model underestimates MSA concentrations over the
North Atlantic throughout the growing season, suggesting that DMS emission in the modcl may be too low. Andreae et al. [1994] has pointed out that DMS seawater concentrations in the North Atlantic are higher than given by the compilation of Bates et al. [1987] which is used here to specify DMS emission; however, the model does not underestimate the DMS surface air observations over the North Atlantic (Table 4). An alternate explanation is that the removal of MSA in that region may be too fast because of excessive precipitation in the GCM, as discussed above in the case of $\mathrm{SO}_{4}{ }^{2-}$. The model also does not capture the high concentrations over the North Pacific in April-May, which could reflect a spring maximum in DMS emission. The MSA concentrations simulated by the model at sites in the tropics and in the southern hemisphere are generally within a factor of 2 of observed values, except that the summer values are too high at Palmer.

Results for MSA at altitude are compared with the few available observations in Figure 14. At midlatitudes the model captures well the observed decrease of concentrations with altitude reflecting scavenging by precipitation. Over the tropics, the model predicts relatively high MSA concentrations at high altitude because of production from DMS transported aloft by convection (Figure 4). No observed vertical profiles in tropical maritime air are however available for testing this model result. Observations over the Amazon show a decrease from the boundary layer to the free troposphere, while the model shows the reverse, reflecting the same problem as discussed earlier for $\mathrm{SO}_{4}{ }^{2-}$.

Figure 15 shows the $\mathrm{MSA} \mathrm{SO}_{4}{ }^{2-}$ molar concentration ratios in the model and observations. This ratio has been used extensively to estimate the biogenic fraction of $\mathrm{SO}_{4}{ }^{2-}$ over the oceans and to 
Table 6. Observed and Simulated $\mathrm{SO}_{4}{ }^{2-}$ Concentrations in Surface Air

\begin{tabular}{|c|c|c|c|c|}
\hline \multirow{2}{*}{ Site } & \multirow{2}{*}{ Period } & \multicolumn{2}{|c|}{$\mathrm{SO}_{4}^{2-\mathrm{a}} \mathrm{ppt}$} & \multirow{2}{*}{ Reference $^{b}$} \\
\hline & & Observed & Model & \\
\hline \multicolumn{5}{|c|}{ Industrial Region } \\
\hline A. Langenbrugge, Germany & 1986-1992 & 1580 & 1700 & EMEP \\
\hline B. Illmitz, Austria & 1986-1992 & 1640 & 1900 & EMEP \\
\hline C. Ispra, Italy & 1986-1992 & 2000 & 1670 & EMEP \\
\hline D. Whiteface Mtn., New York, U.S. & $1975-1988$ & 838 & 889 & HD \\
\hline E. Albany, New York, U.S. & July 1983 - Feb. 1985 & 1510 & 1780 & HD \\
\hline F. Mayville, New York, U.S. & $1981-1988$ & 1480 & 2150 & HD \\
\hline G. Ohio, U.S. & May 1980 - Aug. 1981 & 1640 & 2150 & SP \\
\hline H. Indiana, U.S. & May 1980 - Aug. 1981 & 1850 & 2230 & SP \\
\hline I. Kentucky, U.S. & May 1980 - Aug. 1981 & 1850 & 2010 & SP \\
\hline \multicolumn{5}{|c|}{ Arctic and Subarctic } \\
\hline J. Spitzsbergen, Norway & $1986-1992$ & 144 & 182 & EMEP \\
\hline K. Bear Island, Norway & Oct. 1978 - Sept. 1981 & 352 & 175 & HL \\
\hline L. Jergul, Norway & $1986-1992$ & 406 & 293 & EMEP \\
\hline M. Janiskoski, Russia & $1986-1992$ & 459 & 361 & EMEP \\
\hline N. Alent, Canada & June 1980 - Dec. 1990 & 213 & 85 & LB \\
\hline O. Mould Bay, Canada & July 1979 - June 1980 & 228 & 111 & BA \\
\hline P. Igloolik, Canada & Nov. 1979 - June 1980 & 250 & 140 & BA \\
\hline Q. Heimaey, Iceland & July $1987-$ June 1993 & 159 & 128 & PR, SAu \\
\hline R. Cree Lake, Canada & $1982-1988$ & 192 & 435 & BB \\
\hline \multicolumn{5}{|c|}{ Ocean and Antarctic } \\
\hline S. Mace Head & Aug. 1988 - June 1993 & 322 & 358 & GA, SA1, SAu \\
\hline T. Bermuda & April 1989 - June 1993 & 559 & 281 & GA, SA1, SAu \\
\hline U. Barbados & May 1984 - June 1993 & 204 & 84 & GA, SAl, SAu \\
\hline V. Midway Island & Jan. 1981 - Jan. 1993 & 143 & 71 & SA2, SAu \\
\hline W. Oahu & Jan. 1981 - Jan. 1993 & 135 & 87 & $\mathrm{SA} 2, \mathrm{SAu}$ \\
\hline X. Fanning & April 1981 - July 1987 & 174 & 177 & SA2, SAu \\
\hline Y. American Samoa & March 1983 - April 1992 & 98 & 85 & SA3 \\
\hline Z. New Caledonia & Aug. 1983 - Oct. 1985 & 112 & 66 & $\mathrm{SA} 2, \mathrm{SAu}$ \\
\hline A'. Norfolk Island & May 1983 - Dec. 1990 & 75 & 55 & $\mathrm{SA} 2, \mathrm{SAu}$ \\
\hline B'. Cape Grim & Aug. 1976 - June 1984 & $95^{\mathrm{c}}$ & 69 & AY1 \\
\hline Cape Grim & Nov. 1988 - May 1990 & $20^{d}$ & 69 & AY2 \\
\hline C'. Palmer, Antarctica & April 1990 - June 1991 & 25 & 148 & SA4 \\
\hline D'. Mawson, Antarctica & Feb. 1987 - Dec. 1991 & 29 & 56 & SA4 \\
\hline
\end{tabular}

annual mean concentrations excluding the sea-salt component.

b References are AY1, Ayers et al. [1986]; AY2, Ayers et al. [199]1; BA, Barrie et al. [1989]; BB, Barrie and Bottenheim [1990]; EMEP, Norwegian Institutue for Air Research [1988-1994]; GA, Galloway et al. [1993]; HD, Husain and Dutkiewicz [1990]; HL, Heintzenherg and Larssen [1983]; LB, Li and Barrie [1993]; PR, Prospero et al. [1995]; SA1, D. L. Savoie et al. (Oceanic antrhopogenic contributions to non-sea-salt sulfate in the maine boundary layer over the North Atlantic Ocean, submitted to Journal of Geophysical Research, 1995); SA2, Savoie et al. [1989b]; SA3, Savoie et al. [1994]; SA4, Savoie et al. [1993]; SAu, D. L. Savoie, (unpublished data, 1995); SP, Shaw and Paur [1983].

c Upper limit, since data may have sea-salt contamination.

d Lower limit, since data include only sub-micrometer size acrosol to avoid sea-salt contamination.

test our understanding of DMS oxidation pathways [e.g., Saltzman et al., 1985; Savoie and Prospero, 1989; Berresheim et al., 1990; Ayers et al., 1991]. Figure 15 shows that the magnitudes and seasonal variations of the $\mathrm{MSA} / \mathrm{SO}_{4}{ }^{2-}$ ratio at marine sites are generally well reproduced by the model, reflecting in part our assumption of an additional DMS oxidant $(X)$ with $100 \% \mathrm{SO}_{2}$ product yield.

The MSA $/ \mathrm{SO}_{4}{ }^{2-}$ concentration ratios at extratropical sites peak in summer, both in the observations and in the model. This pattern would be expected for sites where $\mathrm{SO}_{4}{ }^{2-}$ has a strong anthropogenic contribution (Mace Head and Bermuda); but in remote oceanic regions, where both $\mathrm{MSA}$ and $\mathrm{SO}_{4}{ }^{2-}$ are primarily from DMS oxidation, one might expect a maximum $\mathrm{MSA} / \mathrm{SO}_{4}{ }^{2-}$ ratio in winter because the addition branch of the DMS + $\mathrm{OH}$ reaction, yielding MSA, is favored at lower temperatures [Hynes et al., 1986]. The observed $\mathrm{MSA} / \mathrm{SO}_{4}{ }^{2-}$ seasonal variation thus suggests the presence of important DMS oxidants other than $\mathrm{OH}$. We find in our model that oxidation by $\mathrm{NO}_{3}$ (leading to $\mathrm{SO}_{4}{ }^{2-}$ formation) can provide a significant sink for DMS in winter; for example, oxidation of DMS by $\mathrm{NO}_{3}$ in winter at Cape Grim can be up to 3 times more efficient than by $\mathrm{OH}$. The additional DMS oxidant $X$ postulated in the model further contributes to lowering the $\mathrm{MSA} / \mathrm{SO}_{4}{ }^{2-}$ ratio in winter. Simulated $\mathrm{MSA} / \mathrm{SO}_{4}{ }^{2-}$ ratios are too low at both Antarctic coastal sites of Palmer and Mawson and at Heimaey, Iceland, particularly in summer; this discrepancy could reflect uncertainty in the $\mathrm{SO}_{4}{ }^{2-}$ yield from the $\mathrm{DMS}+\mathrm{OH}$ addition channel [Berresheim et al., 1995].

\section{Global Budget}

The global, annual mean sulfur budget in the model is summarized in Figure 16. Anthropogenic emission accounts for nearly 

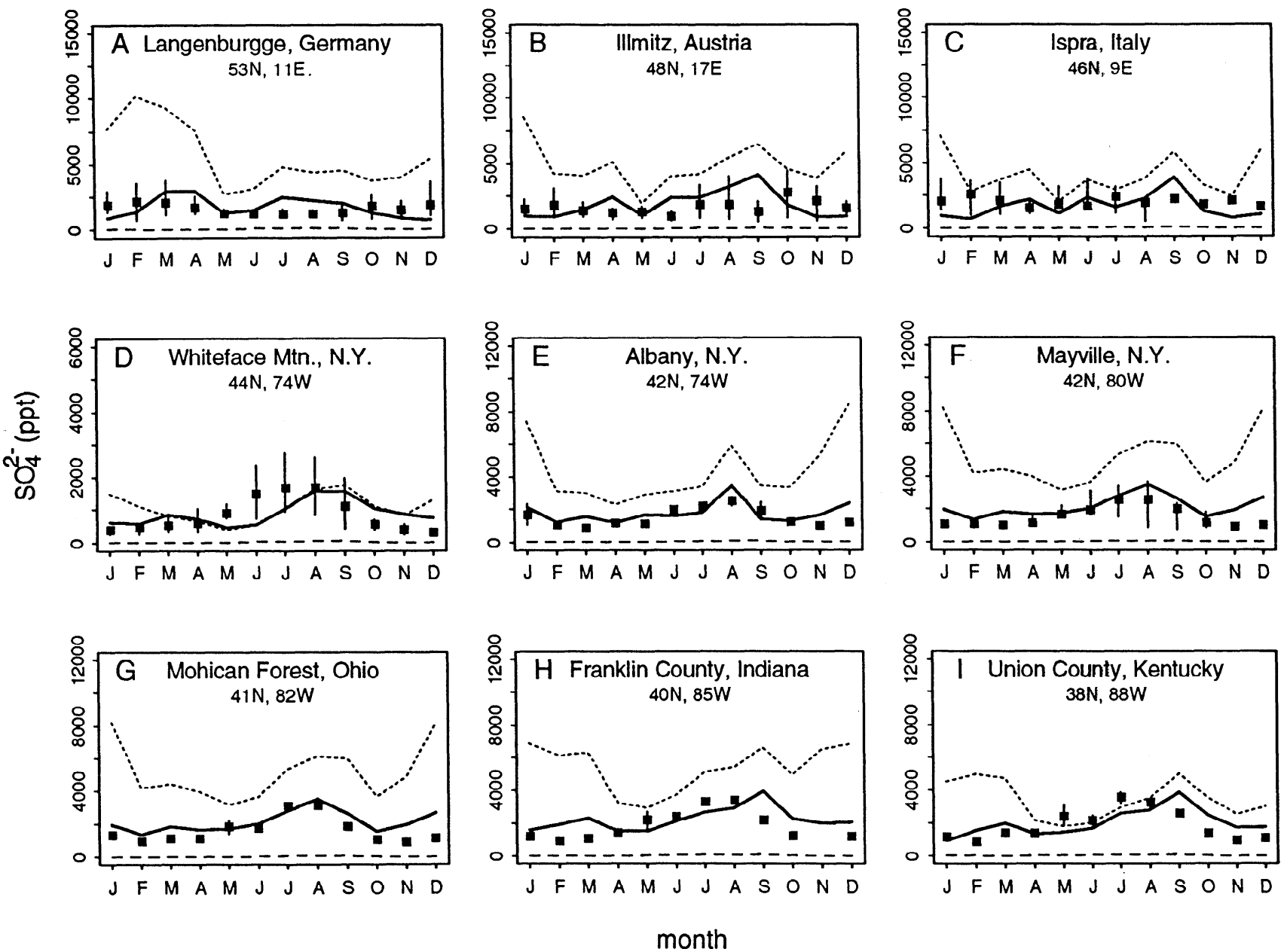

Figure 11a. Seasonal variations of observed (squares) and simulated (lines) monthly mean $\mathrm{SO}_{4}{ }^{2-}$ concentrations at sites in Europe and the United States. The interannual range of observed means is shown for sites with more than one year of data. References for the observations are given in Table 6. Dashed lines are from a simulation without anthropogenic emissions. Dotted lines are from a simulation including no $\mathrm{H}_{2} \mathrm{O}_{2}$ limitation of in-cloud $\mathrm{SO}_{2}$ oxidation.

$70 \%$ of the total sulfur source of $97 \mathrm{Tg} \mathrm{S} \mathrm{yr}^{-1}$. Two-thirds of sulfur in the atmosphere is removed by wet deposition, and the rest is removed by dry deposition. This budget is compared in Table 9 to budgets previously reported by Langner and Rodhe [1991] (LR91), Pham et al. [1995] (P95) and Feichter et al. [1996] (F96) from their global three-dimcnsional models.

The global DMS emission flux (22 $\left.\mathrm{Tg} \mathrm{S} \mathrm{yr}^{-1}\right)$ in our model is slightly higher than those of LR91 (16 $\left.\mathrm{Tg} \mathrm{S} \mathrm{yr}^{-1}\right), \mathrm{P}^{-1}$ (20 $\mathrm{Tg} \mathrm{S} \mathrm{yr}^{-}$ ${ }_{1}^{1}$ ), and F96 (17 Tg S yr$\left.{ }^{-1}\right)$. Our global burden of DMS $(0.059 \mathrm{Tg}$ S) is comparable to that of P95 but a factor of 2 lower than that of LR91 and F96. The difference reflects the 3-day lifetime of DMS in LR91 and 2-day in F96 (as compared to 1.0 days in our model). In the LR91 model, the only DMS oxidant is $\mathrm{OH}$; we find in our model a mean lifetime of 2.6 days for DMS against reaction with $\mathrm{OH}$, consistent with LR91. As discussed above, however, reaction with $\mathrm{OH}$ alone appears insufficient to balance the budget of DMS in marine air. The difference in DMS lifetime between our model and F96 is because we double the DMS oxidation rate from reactions with $\mathrm{OH}$ and $\mathrm{NO}_{3}$ by introducing an additional oxidant $\mathrm{X}$; otherwise the DMS lifetime in our model would be similar to that in F96. Based on our evaluation of DMS with observations, it seems that the DMS burdens in LR91 and F96 might be too high.
As shown in LR91, their DMS concentrations in winter appear in particular to be excessive. There is no comparison of DMS concentrations with observations given in F96.

The agreement between the global DMS burdens in our model and P95 reflects similar lifetimes for DMS in the two models (1.0 days). However, P95 obtained this short lifetime by invoking only $\mathrm{OH}$ and $\mathrm{NO}_{3}$ as oxidants. In our model, $\mathrm{OH}$ and $\mathrm{NO}_{3}$ yield a DMS lifetime of 2.0 days, and doubling this loss rate is required to reduce the DMS burden to values consistent with observations. Inspection of the $\mathrm{OH}$ fields used by $\mathrm{P} 95$, as given in Müller and Brasseur [1995], shows no large differences with the OH fields used in our model, and the contribution of DMS $+\mathrm{NO}_{3}$ to total DMS loss (not counting the additional DMS $+X$ reaction) is higher in our model than in P95. One possible explanation for the difference in DMS lifetimes could be a greater extratropical contribution to the global DMS loading in our model. Emission of DMS was distributed in P95 solely as a function of solar radiation, thus DMS in P95 would be more concentrated at lower latitudes where $\mathrm{OH}$ concentrations are high.

Our global source and lifetime of $\mathrm{SO}_{2}$ are close to those reported by LR91 and F96 but significantly different from P95. The global source of $\mathrm{SO}_{2}$ in $\mathrm{P} 95$ is $30 \%$ larger than in our model 

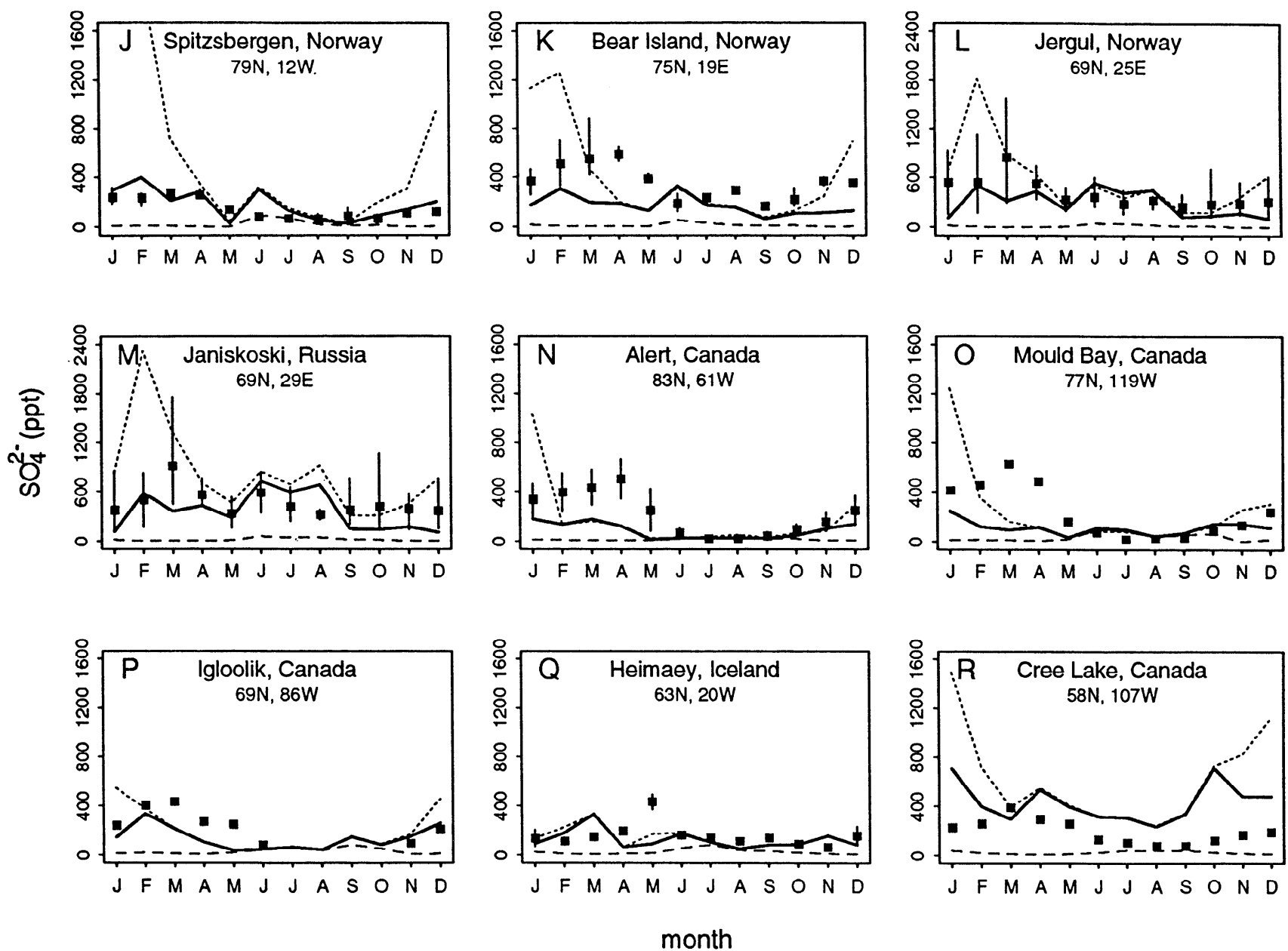

Figure 11b. Same as Figure 11a but for Arctic and subarctic regions.

(123 versus $96 \mathrm{Tg} \mathrm{S} \mathrm{yr}^{-1}$ ), owing to larger emissions from fossil fuel combustion and industrial activities. Despite this larger source, the $\mathrm{SO}_{2}$ burden in $\mathrm{P} 95$ is only $60 \%$ of that in our model $(0.2$ versus $0.34 \mathrm{Tg} \mathrm{S})$, reflecting a much shorter lifetime for $\mathrm{SO}_{2}(0.6$ versus 1.3 days). $\mathrm{P} 95$ assumed a uniform $\mathrm{SO}_{2}$ deposition velocity of $0.9 \mathrm{~cm} \mathrm{~s}^{-1}$ over continents, which is clearly excessive on a $24-$ hour average basis since stability suppresses deposition at night. In addition, $\mathrm{P} 95$ assumed that in-cloud oxidation of $\mathrm{SO}_{2}$ is not limited by the supply of $\mathrm{H}_{2} \mathrm{O}_{2}$; however, as shown above, $\mathrm{H}_{2} \mathrm{O}_{2}$ is much less than $\mathrm{SO}_{2}$ over the polluted continents. LR91 also neglected the limitation of $\mathrm{SO}_{2}$ oxidation by the supply of $\mathrm{H}_{2} \mathrm{O}_{2}$, but their loss rate of $\mathrm{SO}_{2}$ from in-cloud oxidation is comparabie to that in our model. Differences in cloud processing frequencies may explain this result.

Our global $\mathrm{SO}_{4}{ }^{2-}$ burden $(0.53 \mathrm{Tg} \mathrm{S})$ is much less than those of LR91 (0.77 Tg S) and P95 (0.8 Tg S), but close to that of F96 (0.61 $\mathrm{Tg} \mathrm{S})$. The discrepancy appears to be driven principally by $\mathrm{SO}_{4}{ }^{2-}$ concentrations in the free troposphere of the northern hemisphere. For example, north of $30^{\circ} \mathrm{N}$ above $400 \mathrm{mbar}$, the average $\mathrm{SO}_{4}{ }^{2-}$ concentration is $100-250 \mathrm{ppt}$ in LR91 and $250 \mathrm{ppt}$ in P91, while it is 50-100 ppt in F96 and only 25-50 ppt in our model (Figure 5). An important cause for the discrepancy appears to be differences between the models in the wet scavenging schemes for $\mathrm{SO}_{2}$ and $\mathrm{SO}_{4}{ }^{2-}$. Our model and $\mathrm{F} 96$ account for scavenging in wet convective updrafts, thereby greatly restricting the transport of $\mathrm{SO}_{2}$ and $\mathrm{SO}_{4}{ }^{2-}$ to high altitudes; this efficient scavenging was indirectly taken into account in LR91 by eliminating the convective transport of $\mathrm{SO}_{2}$ and $\mathrm{SO}_{4}{ }^{2-}$, but was not considered in P95. Aerosol scav-
Table 7. Observed and Simulated Sulfur Wet Deposition Flux

\begin{tabular}{|c|c|c|c|}
\hline \multirow{2}{*}{ Site } & \multicolumn{2}{|c|}{ Flux ${ }^{\mathrm{a}}, \mathrm{mg} \mathrm{S} \mathrm{m}^{-2} \mathrm{yr}^{-1}$} & \multirow{2}{*}{ Reference $^{b}$} \\
\hline & Observed & Model & \\
\hline \multicolumn{4}{|c|}{ Continent and Arctic } \\
\hline A. Eastern U.S. ${ }^{c}$ & 703 & 704 & NAPAP \\
\hline B. Western U.S. ${ }^{c}$ & 153 & 150 & NAPAP \\
\hline C. Western Europe ${ }^{d}$ & 1020 & 1180 & EMEP \\
\hline D. Amazon Basin, Brazil & 130 & 113 & AN \\
\hline E. Lake Calado, Brazil & 120 & 129 & GA1 \\
\hline F. San Carlos, Venezuela & 170 & 88 & GA2 \\
\hline G. Katherine, Australia & 70 & 66 & LK \\
\hline H. Dye 3, Greenland & 4 & 20 & HE \\
\hline I. Poker Flat, Alaska & 32 & 54 & GA2 \\
\hline \multicolumn{4}{|c|}{ Ocean } \\
\hline J. Bermuda & 230 & 356 & GA2 \\
\hline K. American Samoa & 66 & 34 & PS \\
\hline L. Amsterdam Island & 44 & 59 & NG \\
\hline M. New Zealand & 67 & 52 & PD \\
\hline N. Central Tasman Sea & 130 & 66 & PD \\
\hline O. Macquarie Island & 67 & 89 & $\mathrm{AR}$ \\
\hline
\end{tabular}

a Annual means, excluding the sea-salt component over the oceans.

${ }^{b}$ References are AN, Andreae et al. [1990b]; AR, Ayers and Ramsdale [1988]; EMEP, Norwegian Institute for Air Research [1988-1994]; GA1, Galloway [1985]; GA2, Galloway et al. [1982]; HE, Herron [1982]; LK, Likens et al. 1987; NAPAP, National Acid Precipitation Assessment Program [1992]; NG, Nguyen et al. [1992]; PD, A. A. Pszenny and R. A. Duce (unpublished data from Galloway [1985]); PS, Pszenny et al. [1982].

${ }^{c}$ Eastern United States, east of $92^{\circ} \mathrm{W}$; western United States, west of $102^{\circ} \mathrm{W}$.

${ }^{\mathrm{d}}$ Germany, Austria, Italy, and Belgium. 

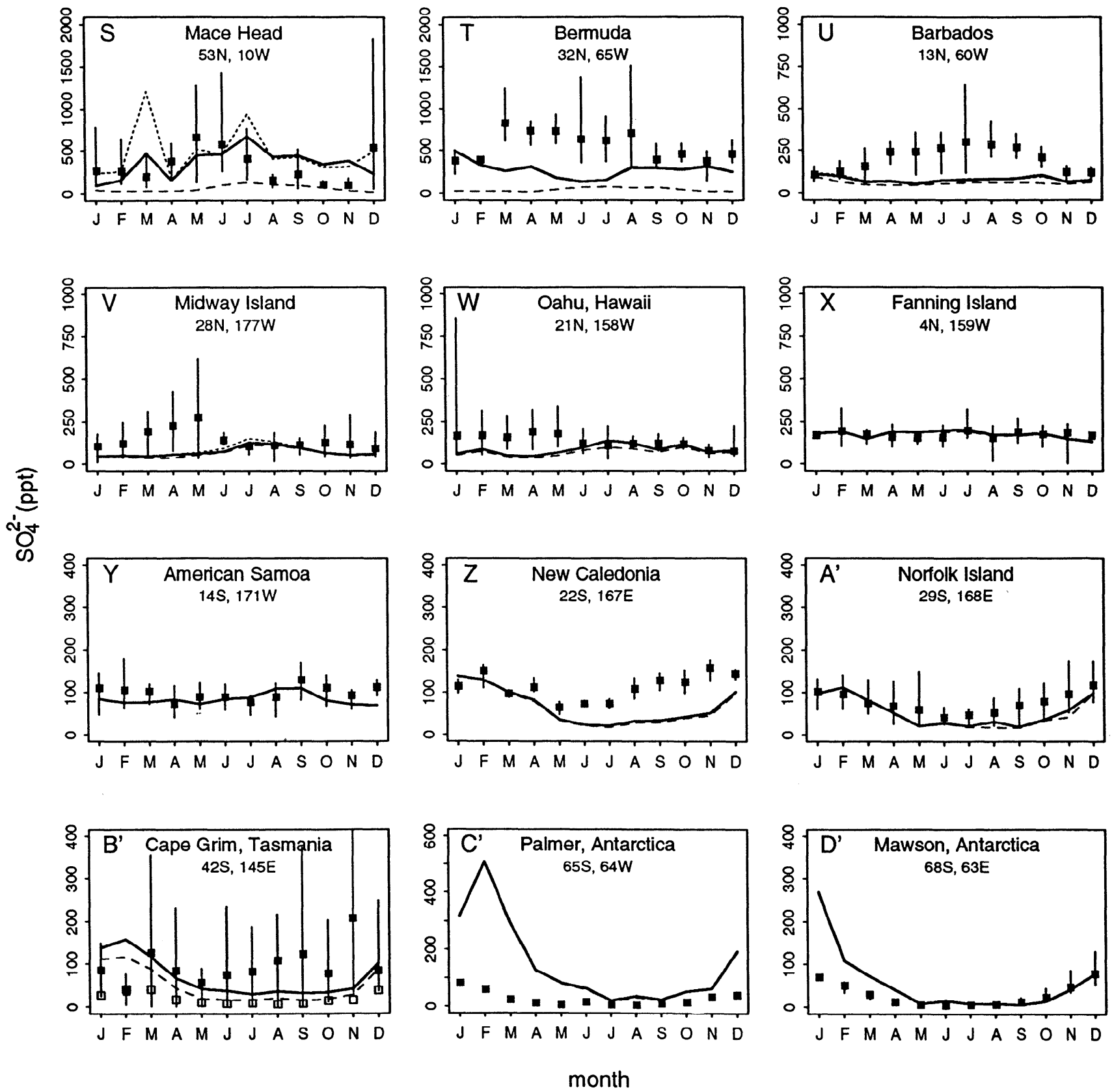

Figure 11c. Same as Figure 11a but for oceans and the Antarctic.

enging in convective precipitation is coupled with wet convective mass transport in our model, while it was computed as a first-order rainout loss in both LR91 and P95. In addition, below-cloud scavenging of $\mathrm{SO}_{4}{ }^{2-}$ was not considered in LR91 and P95. On the other hand, precipitation anomalies in the GISS GCM could also in part contribute to the lower $\mathrm{SO}_{4}{ }^{2-}$ lifetime in our model. Although comparison with the observations in Figure 12 suggests that LR91 and $\mathrm{P} 95$ would overestimate $\mathrm{SO}_{4}{ }^{2-}$ in the upper troposphere, more extensive observations in that region of the atmosphere are needed to evaluate the models.

The mean lifetime of MSA in our model is longer than that of $\mathrm{SO}_{4}{ }^{2-}$ (6.2 versus 3.9 days) because a larger fraction of MSA resides in the free troposphere where precipitation is infrequent
(Figure 4). The global source and lifetime of MSA in our model are in good agreement with values from P95. However, in our model, over $90 \%$ of MSA is removed by wet deposition, whereas in P95 the wet and dry deposition fluxes are comparable because of the assumption of a high dry deposition velocity. LR91 and F96 did not simulate MSA.

Despite the above discrepancies, there are a number of points of agreement between the models. Thus, the contribution of fossil fuel combustion and industrial activities to the global sulfur source is $70-75 \%$ in all four models. The fraction of $\mathrm{SO}_{2}$ removed by deposition before it is oxidized to $\mathrm{SO}_{4}{ }^{2-}$ is about $50 \%$. All four models also agree that oxidation of $\mathrm{SO}_{2}$ to $\mathrm{SO}_{4}{ }^{2-}$ is dominated by in-cloud processes (70-90\% of total oxidation). 

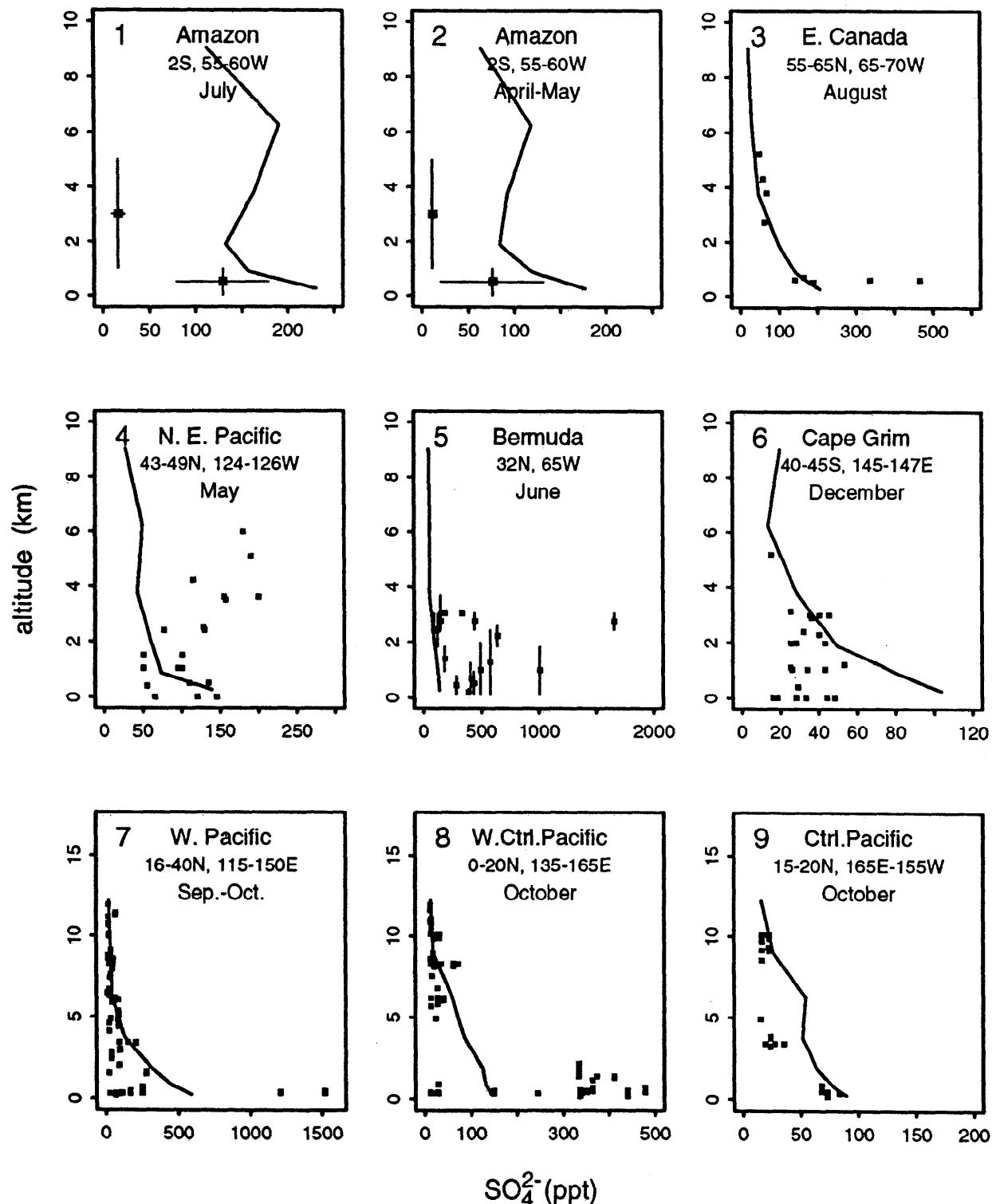

Figure 12. Vertical profiles of sulfate. The squares are observations, and the solid lines are model means for the corresponding locations and months. The observation periods and references are 1 and 2, July 1985 and April - May 1987, respectively [Andreae et al., 1990a]; 3, August 1-14, 1990 [Gorzelska et al., 1994]; 4, May 3-12, 1985 [Andreae et al., 1988]; 5, June 1986 [Luria et al., 1989]; 6, December 3-18, 1986 [Berresheim et al., 1990 ]; 7 to 9, September 22 to October 6, October 8-18, October 18-20, 1991, respectively (NASA Langley Research Center, PEM-West A data archive).

\section{Conclusions}

We have used a global three-dimensional model based on meteorological input from the GISS GCM II to simulate the atmospheric distributions of $\mathrm{DMS}, \mathrm{SO}_{2}, \mathrm{SO}_{4}{ }^{2-}$, and MSA. Comparisons of model with observations allowed an assessment of current understanding of several aspects of atmospheric sulfur chemistry.

The model generally reproduces to within $30 \%$ the $\mathrm{SO}_{2}$ and $\mathrm{SO}_{4}{ }^{2-}$ concentrations and $\mathrm{SO}_{4}{ }^{2-}$ wet deposition fluxes observed in the United States and Europe. As discussed in the companion paper [Chin and Jacob, this issue], $\mathrm{SO}_{4}{ }^{2-}$ levels over polluted continents are determined by emission of anthropogenic $\mathrm{SO}_{2}$, oxidation of $\mathrm{SO}_{2}$ to $\mathrm{SO}_{4}{ }^{2-}$, deposition of both $\mathrm{SO}_{2}$ and $\mathrm{SO}_{4}{ }^{2-}$, and ventilation of $\mathrm{SO}_{4}{ }^{2-}$. The agreement between model and observations implies some success in our representation of these various processes on continental scales. Most of the conversion of $\mathrm{SO}_{2}$ to $\mathrm{SO}_{4}{ }^{2-}$ is through in-cloud oxidation by $\mathrm{H}_{2} \mathrm{O}_{2}$, and is generally limited by the availability of $\mathrm{H}_{2} \mathrm{O}_{2}$. Accounting for this limitation in models appears to be critical.

Current parameterizations of DMS emission from the ocean are highly uncertain. We find in our model that a global DMS source of $22 \mathrm{Tg} \mathrm{S} \mathrm{yr}^{-1}$ simulates generally to within a factor of 2 , and with no mean global bias, the $\mathrm{SO}_{4}{ }^{2-}$ concentrations and wet deposition fluxes observed at remote marine sites. However, the same source overestimates observed DMS concentrations in marine air by a factor of 2 if $\mathrm{OH}$ and $\mathrm{NO}_{3}$ are taken to be the only DMS oxidants. It is possible that the model may underestimate the concentrations of 

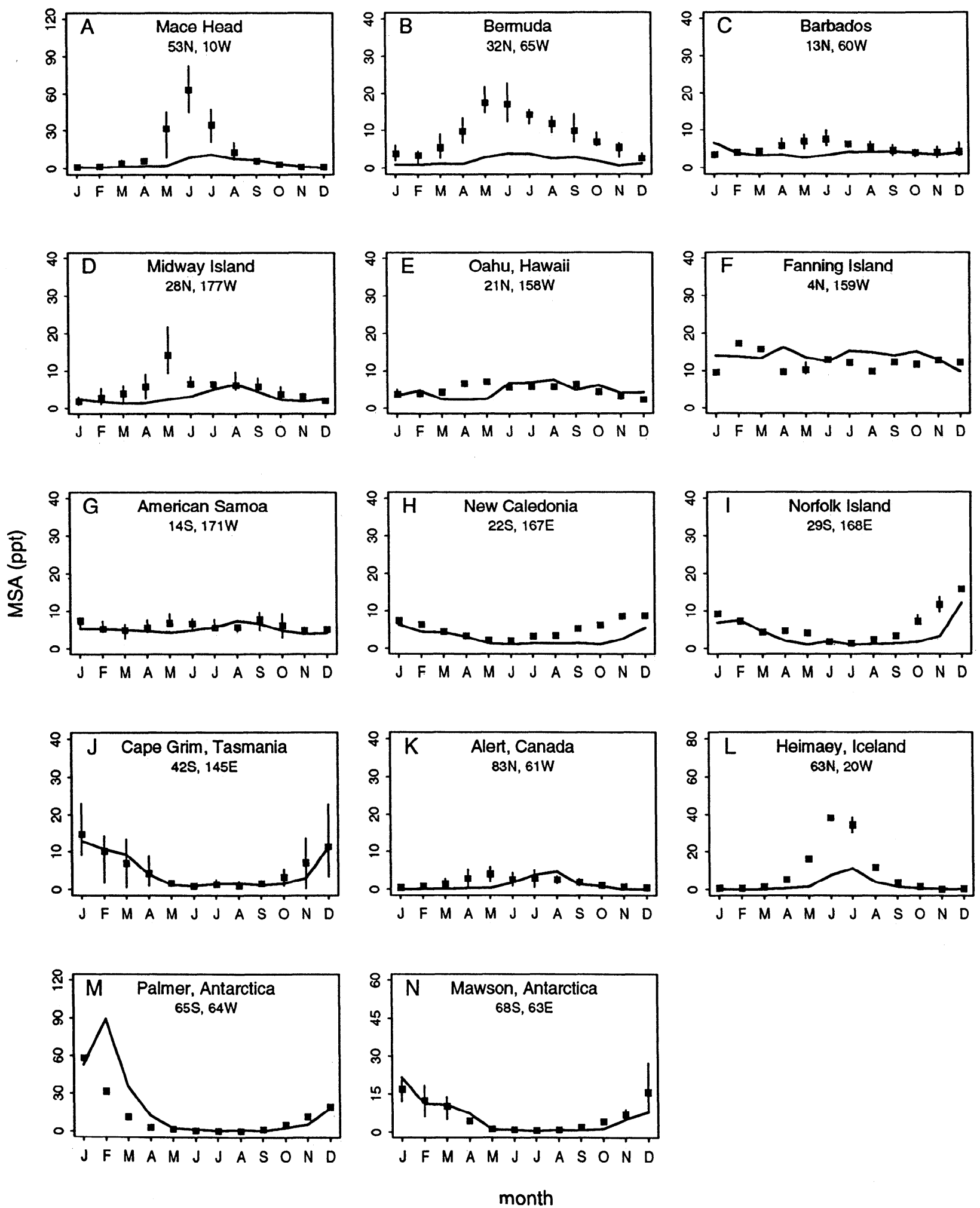

Figure 13. Seasonal variations of observed (squares) and simulated (lines) monthly mean MSA concentrations at Atlantic (panels A-C), Pacific (panels D-J), and polar (panels K-N) sites. The interannual range of observed means is shown for sites with more than one year of data. References for the observations are given in Table 8. 
Table 8. Observed and Simulated MSA Concentrations in Surface Air

\begin{tabular}{|c|c|c|c|c|}
\hline \multirow{2}{*}{ Site } & \multirow{2}{*}{ Period } & \multicolumn{2}{|c|}{$\mathrm{MSA}^{\mathrm{a}}, \mathrm{ppt}$} & \multirow{2}{*}{ Reference $^{b}$} \\
\hline & & Observed & Model & \\
\hline \multicolumn{5}{|c|}{ Ocean } \\
\hline A. Mace Head & Aug. 1988 - June 1993 & 13.8 & 4.1 & GA, SA1, SAu \\
\hline B. Bermuda & April 1989 - June 1993 & 9.0 & 2.1 & GA, SA1, SAu \\
\hline C. Barbados & May 1984 - June 1993 & 5.2 & 4.1 & GA, SA1, SAu \\
\hline D. Midway Island & Jan. 1981 - Jan. 1993 & 5.2 & 2.9 & SA2, SAu \\
\hline E. Oahu & Jan. 1981 - Jan. 1993 & 4.9 & 4.7 & $\mathrm{SA} 2, \mathrm{SAu}$ \\
\hline F. Fanning & April 1981 - July 1987 & 12.0 & 13.7 & SA2, SAu \\
\hline G. American Samoa & March 1983 - April 1992 & 6.0 & 5.2 & SA3 \\
\hline H. New Caledonia & Aug. 1983 - Oct. 1985 & 5.2 & 2.9 & SA2, SAu \\
\hline I. Norfolk Island & May 1983 - Dec. 1990 & 6.1 & 3.7 & SA2, SAu \\
\hline J. Cape Grim & Aug. 1976 - June 1984 & 2.8 & 5.0 & AY \\
\hline \multicolumn{5}{|c|}{ Arctic and Antarctic } \\
\hline K. Alert, Canada & July 1980 - May 1990 & 1.8 & 1.1 & LB \\
\hline L. Heimaey, Iceland & July 1987 - June 1993 & 9.4 & 2.5 & PR, SAu \\
\hline M. Palmer, Antarctica & April 1990 - June 1991 & 12.2 & 18.9 & SA4 \\
\hline N. Mawson, Antarctica & Feb. 1987 - Dec. 1991 & 6.3 & 5.8 & SA4 \\
\hline
\end{tabular}

${ }^{a}$ Annual means.

b References are AY, Ayers et al. [1986]; GA, Galloway et al. [1993]; LB, Li and Barrie [1993]; PR, Prospero et al. [1995]; SA1, D. L. Savoie et al. (submitted manuscript, 1995); SA2, Savoie et al. [1989b]; SA3, Savoie et al. [1994]; SA4, Savoie et al. [1993]; SAu, D. L. Savoie (unpublished data, 1995).

$\mathrm{OH}$ and $\mathrm{NO}_{3}$ in the marine boundary layer; alternatively, we could be missing a major DMS oxidation pathway in the atmosphere. Previous studies of the sulfur budget in the marine boundary layer have found difficulty in closing the DMS budget using reactions with $\mathrm{OH}$ and $\mathrm{NO}_{3}$ as the only sinks for DMS, and additional oxidants have been proposed ( $\mathrm{Cl}, \mathrm{BrO}$, and $\mathrm{O}_{3}$ in clouds). Better understanding of DMS chemistry in the marine boundary layer is obviously needed.

The model does not capture the widespread anthropogenic enhancements of $\mathrm{SO}_{4}{ }^{2-}$ observed over the northern hemisphere oceans in certain seasons. This anomaly was previously identified in a simulation of ${ }^{210} \mathrm{~Pb}$ aerosol using the same model and appears partly due to excessive wet convection in the model downwind of the northern midlatitudes continents.
The concentrations of $\mathrm{SO}_{4}{ }^{2-}$ simulated by the model in the free troposphere agree with the few measurements available from aircraft, and are much lower than values reported in previous global three-dimensional models. The difference is attributed, in part, to our accounting of scavenging of $\mathrm{SO}_{2}$ and $\mathrm{SO}_{4}{ }^{2-}$ in wet convective updrafts. More observations are needed in the free troposphere.

On a global basis, we find that fossil fuel combustion and industrial activities account for $68 \%$ of the global source of $\mathrm{SO}_{2}$. Half of this $\mathrm{SO}_{2}$ is oxidized to produce $\mathrm{SO}_{4}{ }^{2-}$ aerosol; the remainder is lost by deposition ( $30 \%$ dry, $20 \%$ wet). Most of the oxidation of $\mathrm{SO}_{2}$ to $\mathrm{SO}_{4}{ }^{2-}$ is by in-cloud reaction with $\mathrm{H}_{2} \mathrm{O}_{2}(85 \%)$, while the rest is by gas-phase reaction with $\mathrm{OH}(15 \%)$. The companion paper by Chin and Jacob [this issue] analyzes model results further to assess the export of anthropogenic sulfur from polluted continents and the global extent of anthropogenic influence on $\mathrm{SO}_{4}{ }^{2-}$.
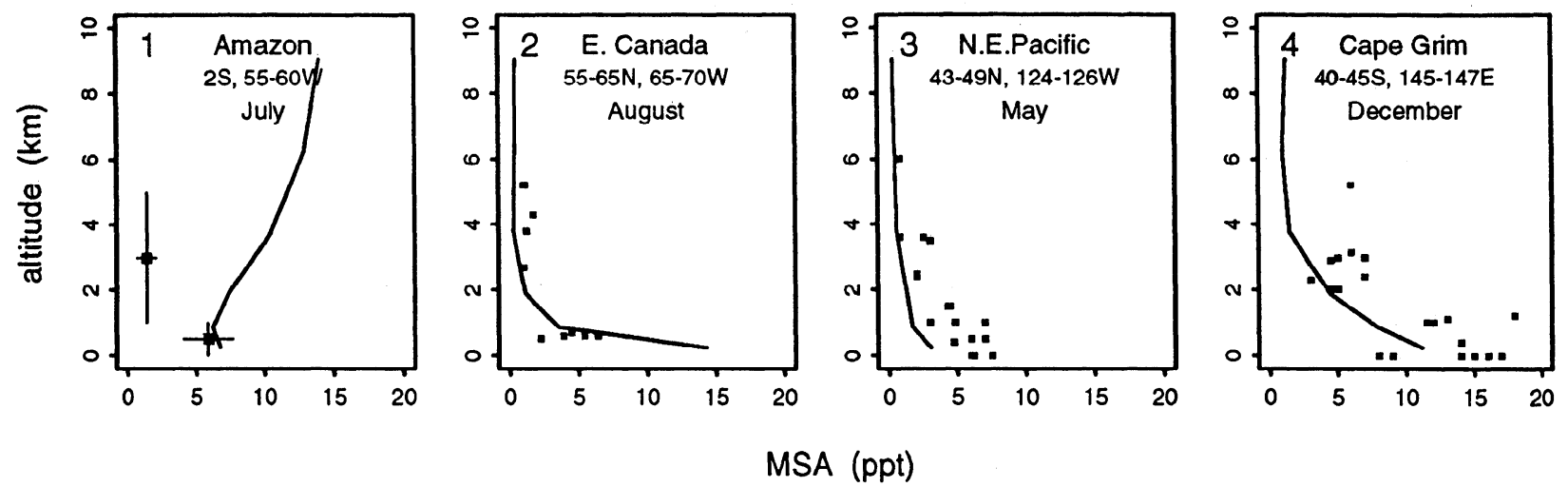

Figure 14. Vertical profiles of MSA. The squares are observations, and the solid lines are model means for the corresponding locations and months. The observation periods and references are 1, July 1985 [Andreae et al., 1990a]; 2, August 1-14, 1990 [Gorzelska et al., 1994]; 3, May 3-12, 1985 [Andreae et al., 1988]; 4, December 3-18, 1986 [Berresheim et al., 1990]. 

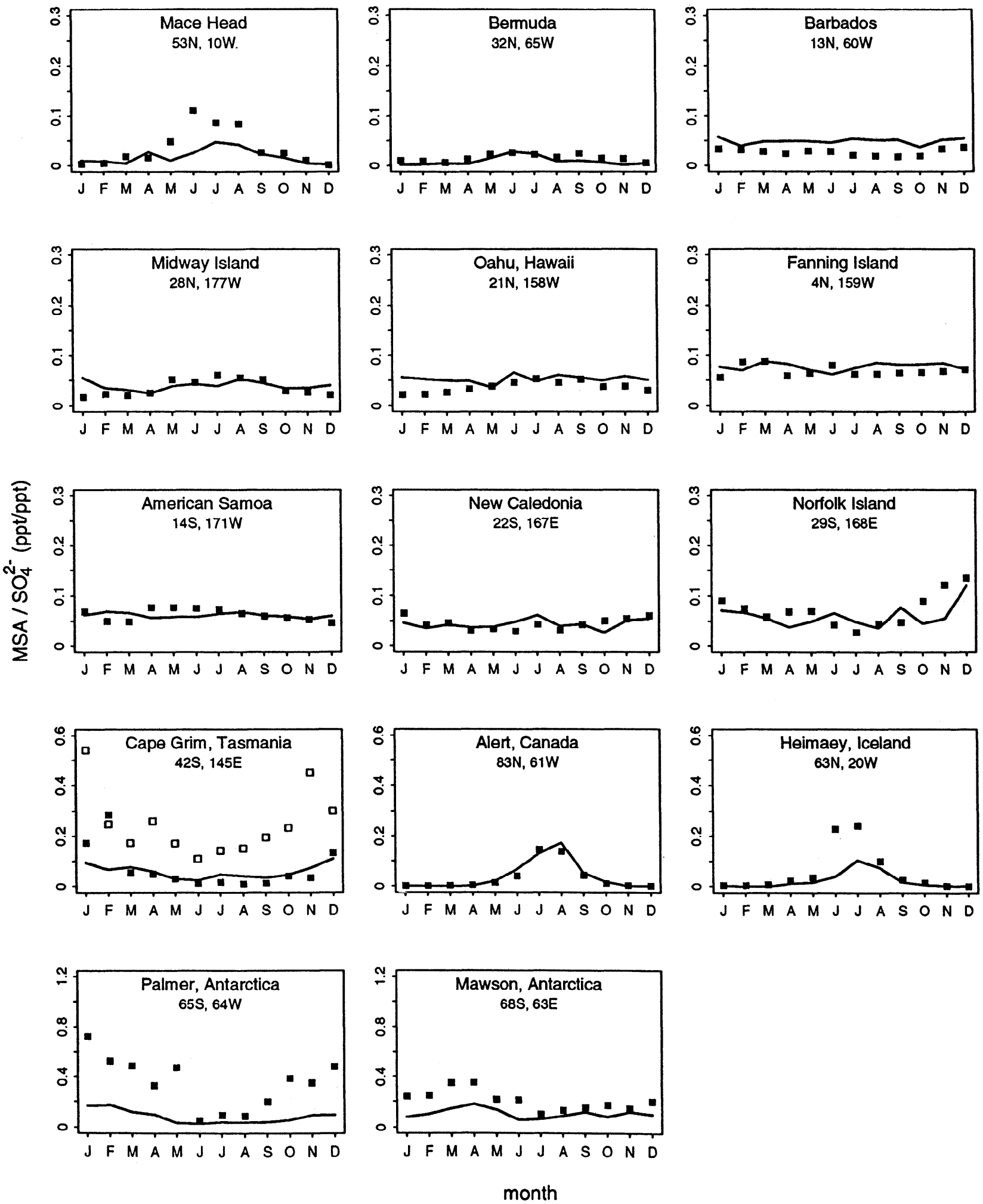

Figure 15. Seasonal variations of observed (squares) and simulated (lines) monthly mean $\mathrm{MSA} \mathrm{SO}_{4}{ }^{2-} \mathrm{molar}$ concentration ratios at marine sites. References for the observations are given in Table 6 for sulfate and Table 8 for MSA. 


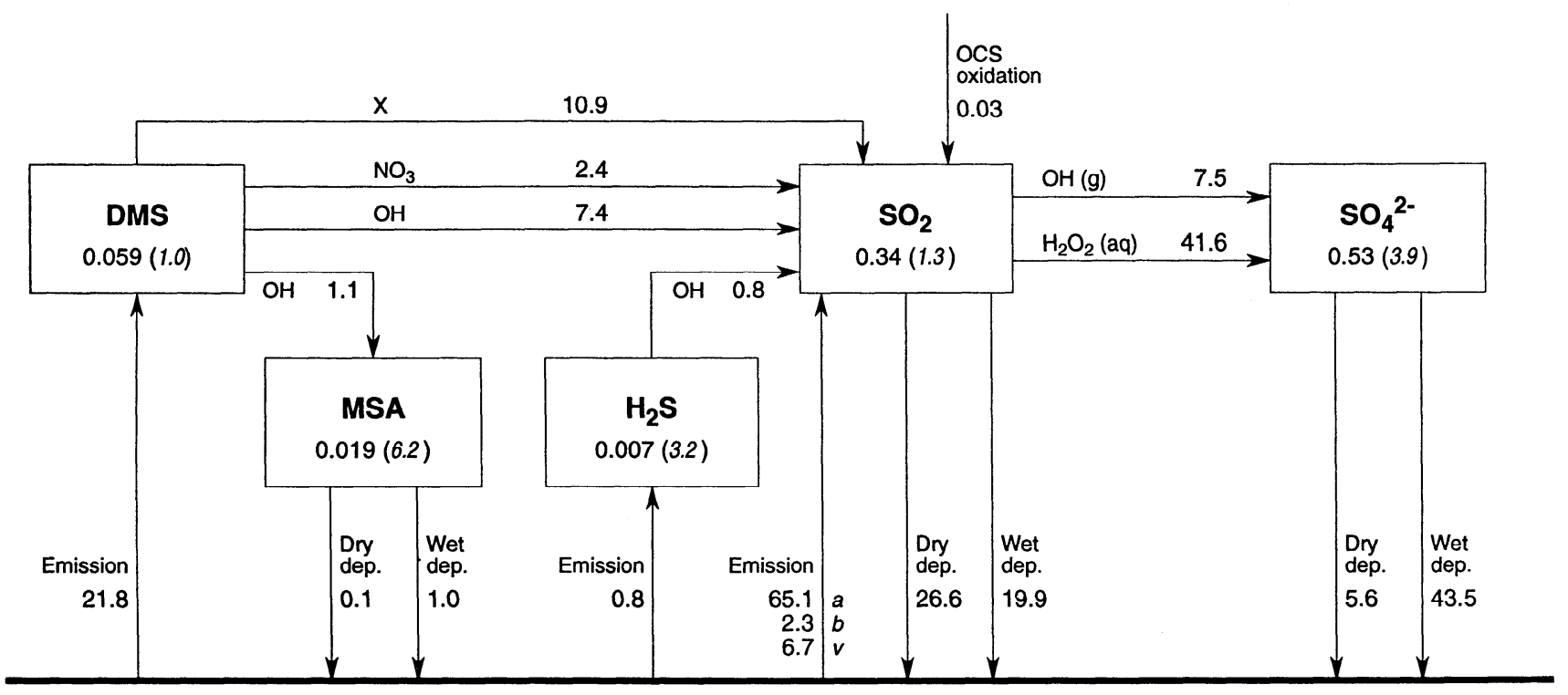

Figure 16. Global sulfur budget in the model. The mass of each compound in the atmosphere $(\mathrm{Tg} S)$ is shown by the numbers inside the boxes. The numbers in parentheses inside the boxes are the lifetimes (days). The emission and deposition fluxes and the oxidation rates $\left(\mathrm{Tg} \mathrm{S} \mathrm{yr}^{-1}\right.$ ) are indicated by arrows. Letters under $\mathrm{SO}_{2}$ emission are: a, anthropogenic emission; $b$, biomass burning emission; $v$, volcanic emission.

Table 9. Global Sulfur Budgets

\begin{tabular}{|c|c|c|c|c|}
\hline & $\begin{array}{c}\text { Langner and Rodhe } \\
\text { [1991] }\end{array}$ & $\begin{array}{l}\text { Pham et al. } \\
\text { [1995] }\end{array}$ & $\begin{array}{c}\text { Feichter et al. } \\
\text { [1996] }\end{array}$ & This Work \\
\hline \multicolumn{5}{|c|}{$D M S$} \\
\hline Source & 16.0 & 20.0 & 16.9 & 21.8 \\
\hline Emission & $16.0(100 \%)$ & $20.0(100 \%)$ & $16.9(100 \%)$ & $21.8(100 \%)$ \\
\hline Sink & 16.0 & 20.0 & 16.9 & 21.8 \\
\hline Reaction with $\mathrm{OH}$ & $16.0(100 \%)$ & $17.2^{\mathrm{a}}(86 \%)$ & $14.6(86 \%)$ & $8.5(39 \%)$ \\
\hline Reaction with $\mathrm{NO}_{3}$ & & $2.8^{\mathrm{a}}(14 \%)$ & $2.3(14 \%)$ & $2.4(11 \%)$ \\
\hline Other reactions & & & & $10.9(50 \%)$ \\
\hline Burden & 0.13 & 0.05 & 0.10 & 0.059 \\
\hline Lifetime & 3.0 & 0.9 & 2.2 & 1.0 \\
\hline \multicolumn{5}{|c|}{$\mathrm{SO}_{2}$} \\
\hline Source & 94.5 & 122.8 & 100.5 & 95.6 \\
\hline Anthropogenic emission & $66.5(70 \%)$ & $92.0(75 \%)$ & $77.6(77 \%)$ & $65.1(68 \%)$ \\
\hline Biomass burning & $2.5(3 \%)$ & $2.9(2 \%)$ & $2.5(2.5 \%)$ & $2.3(2 \%)$ \\
\hline Volcanoes & $8.5(9 \%)$ & $9.2(8 \%)$ & $3.5(3.5 \%)$ & $6.7(7 \%)$ \\
\hline Photochemical production & $17.0(18 \%)$ & $18.7(15 \%)$ & $16.9(17 \%)$ & $21.5(23 \%)$ \\
\hline Sink & 94.5 & 122.8 & 100.5 & 95.6 \\
\hline Gas-phase oxidation & $7.8(8 \%)$ & $6.5(5 \%)$ & $16.8(17 \%)$ & $7.5(8 \%)$ \\
\hline In-cloud oxidation & $42.0(44 \%)$ & $55.5(45 \%)$ & $34.5(34 \%)$ & $41.6(43 \%)$ \\
\hline Dry deposition & $30.5(32 \%)$ & $55(45 \%)$ & $40.2(40 \%)$ & $26.6(28 \%)$ \\
\hline Wet deposition & $14.2(15 \%)$ & $50(4 \%)$ & $9.0(9 \%)$ & $19.9(21 \%)$ \\
\hline Burden & 0.3 & 0.2 & 0.43 & 0.34 \\
\hline Lifetime & 1.2 & 0.6 & 1.5 & 1.3 \\
\hline \multicolumn{5}{|c|}{$\mathrm{SO}_{4}^{2-}$} \\
\hline Source & 53.3 & 62 & 51.3 & 49.1 \\
\hline Anthropogenic emission & $3.5(6 \%)$ & & & \\
\hline Gas-phase production & $7.8(15 \%)$ & $6.5(10 \%)$ & $16.8(33 \%)$ & $7.5(15 \%)$ \\
\hline In-cloud production & $42.0(79 \%)$ & $55.5(90 \%)$ & $34.5(67 \%)$ & $41.6(85 \%)$ \\
\hline Sink & 53.1 & 62.0 & 51.3 & 49.1 \\
\hline Dry deposition & $8.6(16 \%)$ & $17.0(27 \%)$ & $6.7(13 \%)$ & $5.6(11 \%)$ \\
\hline Wet deposition & $41.5(84 \%)$ & $45.0(73 \%)$ & $44.6(87 \%)$ & $43.5(89 \%)$ \\
\hline Burden & 0.77 & 0.8 & 0.61 & 0.53 \\
\hline Lifetime & 5.3 & 4.7 & 4.3 & 3.9 \\
\hline \multicolumn{5}{|c|}{$M S A$} \\
\hline Source & & 1.2 & & 1.1 \\
\hline Chemical production & & $1.2(100 \%)$ & & $1.1(100 \%)$ \\
\hline Sink & & 1.2 & & 1.1 \\
\hline Dry deposition & & $0.5(42 \%)$ & & $0.07(6 \%)$ \\
\hline Wet deposition & & $0.7(58 \%)$ & & $1.04(94 \%)$ \\
\hline Burden & & 0.02 & & 0.019 \\
\hline Lifetime & & 6.1 & & 6.2 \\
\hline
\end{tabular}

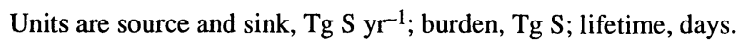

${ }^{a}$ From Pham et al. [1996]. 
Acknowledgments. Comments from H. Rodhe, S. E. Schwartz, and an anonymous reviewer are gratefully acknowledged. This work was supported by grants to Harvard University (National Science Foundation, NSF-ATM-93-04217 and NSF-ATM-93-20778; National Aeronautics and Space Administration, NASA-NAGW-2632; and the Packard Foundation), and grants to University of Miami (National Science Foundation, the Sea-Air Exchange and Atmosphere/Ocean Chemistry programs; NASA, PEM West and Global Backscatter Experiments; and DOE, Remote Atmosphere Measurement Program). MC acknowledges partial support from the Universities Space Research Association and NASA Goddard Space Flight Center (NAS5-32484).

\section{References}

Andreae, M. O., et al., Dimethyl sulfide in the marine atmosphere, J. Geophys. Res., 90, 12,891-12,900, 1985.

Andreae, M. O., H. Berresheim, T. W. Andreae, M. A. Kritz, T. S. Bates, and J. T. Merrill, Vertical distribution of dimethyl sulfide, sulfur dioxide, aerosol ions, and radon over the northeast Pacific Ocean, J. Atmos. Chem., 6, 149-173, 1988.

Andreae, M. O., H. Berresheim, H. Bingemer, D. J. Jacob, B. L. Lewis, S.$\mathrm{M}$. Li, and R. W. Talbot, The atmospheric sulfur cycle over the Amazon Basin, 2, Wet season, J. Geophys. Res., 95, 16,813-16,824, 1990a.

Andreae, M. O., R. W. Talbot, H. Berresheim, and K. M. Beecher, Precipitation chemistry in central Amazonia, J. Geophys. Res., 95, 16,987$16,999,1990 \mathrm{~b}$.

Andreae, T. W., M. O. Andreae, and G. Schebeske, Biogenic sulfur emissions and aerosols over the tropical South Atlantic, 1, Dimethylsulfide in seawater and in the atmospheric boundary layer, J. Geophys. Res., 99, 22,819-22,829, 1994.

Atkinson, R., D. L. Baulch, R. A. Cox, R. F. Hampson Jr., J. A. Derr, and J. Troe, Evaluated kinetics and photochemical data for atmospheric chemistry: Supplement III, J. Phys. Chem. Ref. Data, 88, 881-1097, 1989.

Ayers, G. P., and S. L. Ramsdale, Wet deposition of excess sulfate at Macquarie Island, $54^{\circ} \mathrm{S}, \mathrm{J}$. Atmos. Chem., 7, 317-323, 1988.

Ayers, G. P., J. P. Ivey, and H. S. Goodman, Sulfate and methanesulfonate in the maritime aerosol at Cape Grim, Tasmania, J. Atmos. Chem., 4, 173-185, 1986.

Ayers, G. P., J. P. Ivey, and R. W. Gillett, Coherence between seasonal cycles of dimethyl sulphide, methanesulphonate and sulphate in marine air, Nature, 349, 404-406, 1991.

Balkanski, Y. J., and D. J. Jacob, Transport of continental air to the subantarctic Indian Ocean, Tellus, 42B, 62-75, 1990.

Balkanski, Y. J., D. J. Jacob, R. Arimoto, and M. A. Kritz, Long-range transport of radon-222 over the North Pacific Ocean: Implications for continental influence, J. Atmos. Chem., 14, 353-374, 1992.

Balkanski, Y. J., D. J. Jacob, G. M. Gardncr, W. C. Graustein, and K. K. Turekian, Transport and residence times of tropospheric aerosols inferred from a global three-dimensional simulation of ${ }^{210} \mathrm{~Pb}, J$. Geophys. Res., 98, 20,573-20,586, 1993.

Bandy, A. R., D. L. Scott, B. W. Blomquist, S. M. Chen, and D. C. Thornton, Low yields of $\mathrm{SO}_{2}$ from dimethyl sulfide oxidation in the marine boundary layer, Geophys. Res. Lett., 19, 1125-1127, 1992.

Barnes, I., K. H. Becker, D. Martin, P. Carlier, G. Mouvier, J. L. Jourdain, G. Laverdet, and G. LeBras, in Biogenic Sulfur in the Environment, ACS Sympo. Ser., 393, edited by E.S. Saltzman and W. J. Cooper, Am. Chem. Soc., Washington, D.C., 1989.

Barrie, L. A., Arctic air pollution: An overview of current knowledge, Atmos. Environ., 20, 643-663, 1986.

Barrie, L. A., and M. J. Barrie, Chemical components of lower tropospheric aerosols in the high arctic: Six years of observations, J. Atmos. Chem., $11,211-226,1990$.

Barrie, L. A., and J. W. Bottenheim, Sulphur and Nitrogen Pollution in the Arctic Atmosphere, in Pollution of the Arctic Atmosphere, ed. by W. T. Sturges, pp. 155-181, Elsevier, New York, 1990.

Barrie, L. A., and R. M. Hoff, The oxidation rate and residence time of sulphur dioxide in the arctic atmosphere, Atmos. Environ., 18, 2711-2722, 1984.

Barrie, L. A., M. P. Olson, and K. K. Oikawa, The flux of anthropogenic sulphur into the arctic from mid-latitudes in 1979/80, Atmos. Environ., 23, 2505-2512, 1989.

Bates, T. S., J. D. Cline, R. H. Gammon, and S. R. Kelly-Hansen, Regional and seasonal variations in the flux of oceanic dimethylsulfide to the atmosphere, J. Geophys. Res., 92, 2930-2938, 1987.
Bates, T. S., J. E. Johnson, P. K. Quinn, P. D. Goldan, W. C. Kuster, D. C. Covert, and C. J. Hahn, The biogeochemical sulfur cycle in the marine boundary layer over the Northeast Pacific Ocean, J. Atmos. Chem., 10, 59-81, 1990.

Benkovitz, C. M., M. T. Scholtz, J. Pacyna, L. Tarrason, J. Dignon, E. C. Voldner, P. A. Spiro, J. A. Logan, and T. E. Graedel, Global gridded inventories of anthropogenic emissions of sulfur and nitrogen, J. Geophys. Res., in press, 1996.

Berresheim, H., Biogenic sulfur emissions from the Subantarctic and Antarctic Oceans, J. Geophys. Res., 92, 13,245-13,262, 1987.

Berresheim, H., M. O. Andreae, G. P. Ayers, R. W. Gillett, J. T. Merrill, V. J. Davis, and W. L. Chameides, Airborne measurements of dimethylsulfide, sulfur dioxide, and aerosol ions over the southern ocean south of Australia, J. Atmos. Chem., 10, 341-370, 1990.

Berresheim, H., P. H. Wine, and D. D. Davis, Sulfur in the atmosphere, in Composition, Chemistry, and Climate of the Atmosphere, edited by $\mathrm{H}$. B. Singh, pp. 251-307, Van Nostrand Rienhold, New York, 1995.

Bingemer, H. G., M. O. Andreae, T. W. Andreae, P. Artaxo, G. Helas, D. J. Jacob, N. Mihalopoulos, and B. C. Nguyen, Sulfur gases and aerosols in and above the equatorial African rain forest, J. Geophys. Res., 97, 6207-6217, 1992.

Bürgermeister, S., R. L. Zimmermann, H.-W. Georgii, H. G. Bingemer, G. O. Kirst, M. Janssen, and W. Ernst, On the biogenic origin of dimethylsulfide: Relation between chlorophyll, ATP, organismic DMSP, phytoplankton species, and DMS distribution in Atlantic surface water and atmosphere, J. Geophys. Res., 95, 20,607-20,615, 1990.

Charlson, R. J., S. E. Schwartz, J. M. Hales, R. D. Cess, J. A. Coakley Jr., J. E. Hansen, and D. J. Hofmann, Climate forcing by anthropogenic aerosols, Science, 255, 423-430, 1992.

Chatfield, R. B., and P. J. Crutzen, Sulfur dioxide in remote oceanic air: Cloud transport of reactive precursors, J. Geophys. Res., 89, 71117132, 1984.

Chatfield, R. B., and P. J. Crutzen, Are there interactions of iodine and sulfur species in marine air photochemistry? J. Geophys. Res., 95, 22,319$22,341,1990$.

Chin, M., and D. D. Davis, A reanalysis of carbonyl sulfide as a source of stratospheric background sulfur aerosol, J. Geophys. Res., 100, 8993 9005, 1995.

Chin, M., and D. J. Jacob, Anthropogenic and natural contributions to atmospheric sulfate: A global model analysis, J. Geophys. Res., this issue.

Chin, M., D. J. Jacob, J. W. Munger, D. D. Parrish, and B. G. Doddridge, Relationship of ozone and carbon monoxide over North America, $J$. Geophys. Res., 99, 14,565-14,573, 1994.

Cooper, D. J., and E. S. Saltzman, Measurements of atmospheric dimethyl sulfide and carbon disulfide in the western Atlantic boundary layer, $J$. Atmos. Chem., 12, 153-168, 1991.

Daum, P. H., S. E. Schwartz, and L. Newman, Acidic and related constituents in liquid-water clouds, J. Geophys. Res., 89, 1447-1458, 1984.

Davidson, C. I., Mechanisms of wet and dry deposition of atmospheric contaminants to snow surfaces, in The Environmental Record in Glaciers and Ice Sheets, edited by H. Oeschger and C. C. Langway Jr., pp. 2951, John Wiley, New York, 1989.

Deacon, E. L., Gas transfer to and across an air-water interface, Tellus, 29, 363-374, 1977.

Del Genio, A. D., and M. S. Yao, Sensitivity of a global climate model to the specification of convective updraft and downdraft mass fluxes, $J$. Atmos. Sci., 45, 2641-2668, 1988.

DeMore, W. B., S. P. Sander, D. M. Golden, R. F. Hampson, C. J. Howard, A. R. Ravishankara, C. E. Kolb, and M. H. Molina, Chemical kinetics and photochemical data for use in stratospheric modeling, JPL Publ., 92-20, 1992.

Environmental Protection Agency (EPA), The 1985 NAPAP emission inventory (version 2): Development of the annual data and modeler's tapes, Rep. EPA-600/7-89-012a, Environ. Prot. Agency, Research Triangle Park, N. C., 1989.

Erickson, D. J., III, A stability dependent theory for air-sea gas exchange, J. Geophys. Res., 98, 8471-8488, 1993.

Feichtcr, J., E. Kjellstrom, H. Rodhe, F. Dentener, J. Lelieveld, and G.-J. Roelofs, Simulation of the tropospheric sulfur cycle in a global climate model, Atmos. Environ., 30, 1693-1708, 1996.

Ferek, R. J., R. B. Chatfield, and M. O. Andreae, Vertical distribution of dimethylsulphide in the marine atmosphere, Nature, 320, 514-516, 1986.

Flocchini, R. G., T. A. Cahill, M. L. Pitchford, R. A. Eldred, P. J. Feeney, and L. L. Ashbaugh, Characterization of particles in the arid west, Atmos. Environ., 15, 2017-2030, 1981. 
Galloway, J. N., The deposition of sulfur and nitrogen from the remote atmosphere: Background paper, in The Biogeochemical Cycling of Sulfur and Nitrogen in the Remote Atmosphere, edited by J. N. Galloway, R. J. Charlson, M. O. Andreae, and H. Rodhe, pp. 143-175, D. Reidel, Norwell, Mass., 1985.

Galloway, J. N., G. E. Likens, W. C. Keene, and M. J. Miller, The composition of precipitation in remote areas of the world, J. Geophys. Res., 87 , 8771-8776, 1982.

Galloway, J. N., D. L. Savoie, W. C. Keene, and J. M. Prospero. The temporal and spatial variability of scavenging ratios for nss-sulfate, nitrate, methanesulfonate and sodium in the atmosphere over the North Atlantic Ocean, Atmos. Environ., 27A, 235-250, 1993.

Gorzelska, K., R. W. Talbot, K. Klemm, B. Lefer, O. Klemm, G. L. Gregory, B. Anderson, and L. A. Barrie, Chemical composition of the atmospheric aerosol in the troposphere over the Hudson Bay Iowlands and Quebec-Labrador regions of Canada, J. Geophys. Res., 99, 1763$1779,1994$.

Hansen, J., G. Russell, D. Rind, P. Stone, A. Lacis, S. Lebedeff, R. Ruedy, and $\mathrm{L}$. Travis, Efficient three-dimensional global models for climate studies: Models I and II, Mon. Weather Rev., 111, 609-662, 1983.

Heintzenberg, J., and S. Larssen, $\mathrm{SO}_{2}$ and $\mathrm{SO}_{4}=$ in the arctic: Interpretation of observations at three Norwegian arctic-subarctic stations, Tellus. $35 B, 255-265,1983$.

Herrmann, J., and W. Jaeschke, Measurements of $\mathrm{H}_{2} \mathrm{~S}$ and $\mathrm{SO}_{2}$ over the Atlantic Ocean, J. Atmos. Chem., 1, 111-123, 1984.

Herron, M. M., Impurity sources of $\mathrm{F}^{-}, \mathrm{Cl}^{-}, \mathrm{NO}_{3}^{-}$, and $\mathrm{SO}_{4}{ }^{-}$in Greenland and Antarctic precipitation, J. Geophys. Res., 87, 3052-3060, 1982.

Hicks, B. B., and P. S. Liss, Transfer of $\mathrm{SO}_{2}$ and other reactive gases across the air-sea interface, Tellus, 28, 348-354, 1976.

Hicks, B. B., D. R. Matt, and R. T. McMillen, A micrometeorological investigation of surface exchange of $\mathrm{O}_{3}, \mathrm{SO}_{2}$ and $\mathrm{NO}_{2}$ : A case study, Boundary Layer Meteorol., 47, 321-336, 1989.

Huebert, B. J., S. Howell, P. Lai, J. E. Johnson, T. S. Bates, P. K. Quinn, V Yegorov, A. D. Clarke, and J. N. Porter, Observations of the atmospheric sulfur cycle on SAGA 3, J. Geophys. Res., 98, 16,985-16,995, 1993.

Husain. L., and V. A. Dutkiewicz, A long-term (1975-1988) study of atmospheric $\mathrm{SO}_{4}{ }^{2-}:$ Regional contributions and concentration trends, Atmos. Environ., 24A, 1175-1187, 1990.

Hynes, A. J., P. H. Wine, and D. H. Semmes, Kinetics and mechanism of OH reactions with organic sulfides, J. Phys. Chem., 90, 4148-4156, 1986.

Intergovernmental Panel on Climate Change, Climate Change 1992, edited by J. T. Houghton et al., WMO/UNEP, Cambridge Univ. Press, New York, 1992.

Jacob, D. J., and M. J. Prather, Radon-222 as a test of convection in a general circulation model, Tellus, 42, 118-134, 1990.

Jacob, D. J., M. J. Prather, S. C. Wofsy, and M. B. McElroy, Atmospheric distribution of ${ }^{85} \mathrm{Kr}$ simulated with a general circulation model, J. Geophys. Res., 92, 6614-6626, 1987.

Jacob, D. J., et al., Simulation of summertime ozone over North America, J. Geophys. Res., 98, 14,797-14,816, 1993a.

Jacob, D. J., J. A. Logan, G. M. Gardner, R. M. Yevich, C. M. Spivakovsky, S. C. Wofsy, S. Sillman, and M. J. Prather, Factors regulating ozone over the United States and its export to the global atmosphere, J. Geophys. Res., 98, 14,817-14,826, $1993 \mathrm{~b}$.

Jacob, D. J., et al., What factors regulate atmospheric aerosol, how have they changed, and how might they change in the future?, in Aerosol Forcing of Climate, cdited by R. J. Charlson and J. Hcitzengcrg, John Wiley, New York, 1995.

Keene, W. C., A. A. P. Pszenny, J. N. Galloway, and M. E. Hawley, Seasalt corrections and interpretation of constituent ratios in marine precipitation, J. Geophys. Res., 91, 6647-6658, 1986.

Koch, D. M., D. J. Jacob, and W. C. Graustein, Vertical transport of aerosols in the troposphere as indicated by ${ }^{7} \mathrm{Be}$ and ${ }^{210} \mathrm{~Pb}$ in a chemical tracer model, J. Geophys. Res., in press, 1996.

Langner, J., and H. Rodhe, A global three-dimensional model of the tropospheric sulfur cycle, J. Atmos. Chem., 13, 225-263, 1991.

Ledwell, J. R., The variation of the gas transfer coefficient with molecular diffusivity, in Gas Transfer at Water Surfaces, edited by W. Brutsaert and G. H. Jirka, pp. 293-302, D. Reidel, Norwell, Mass., 1984.

Lee, Y.-N., and X. Zhou, Aqueous reaction kinetics of ozone and dimethylsulfide and its atmospheric implications, J. Geophys. Res., 99, 35973605, 1994

Levine, S. Z., and S. E. Schwartz, In-cloud and below-cloud scavenging of nitric acid vapor, Atmos. Environ., 16, 1725-1734, 1982.
Li, S.-M., and L. A. Barrie, Biogenic sulfur aerosol in the Arctic troposphere, 1, Contributions to total sulfate, J. Geophys. Res., 98, 20,61320,622, 1993

Likens, G. E., W. C. Keen, J. M. Miller, and J. N. Galloway, Chemistry of precipitation from a remote, terrestrial site in Australia, J. Geophys. Res., 92, 13,299-13,314, 1987.

Luria, M., C. C. Van Valin, J. N. Galloway, W. C. Keene, D. L. Wellman, H. Sievering, and J. F. Boatman, The relationship between dimethyl sulfide and particulate sulfate in the mid-Atlantic Ocean atmosphere, Atmos. Environ., 23, 139-147, 1989.

Matthews, E., Global vegetation and land use: New high-resolution data bases for climate studies, J. Clim. Appl. Meteorol., 22, 474-487, 1983.

Müller, J. F., and Brasseur, IMAGES: A three-dimensional chemical transport model of the global troposphere, J. Geophys. Res., 100, 16,44516,490, 1995.

National Acid Precipitation Assessment Program (NAPAP), Long-term monitoring of atmospheric deposition continues, NAPAP Newslett., 2, (2), 5-10, 1992.

Nguyen, B. C., B. Bonsang, and A. Gaudry, The role of ocean in the global atmospheric sulfur cycle, J. Geophys. Res., 88, 10,903-10,914, 1983.

Nguyen, B. C., N. Mihalopoulos, J. P. Putaud, A. Gaudry, L. Gallet, W. C. Keene, and J. N. Galloway, Covariations in oceanic dimethyl sulfide, its oxidation products and rain acidity at Amsterdam Island in the southern Indian Ocean, J. Atmos. Chem., 15, 39-53, 1992.

Norwegian Institute for Air Research, EMEP Data Report 1986-1992, Part 2, Monthly and seasonal summaries, EMEP/CCC-Reports7/88, 2/89,5/ 90, 3/91,3/92, 5/93, 5/94, Lillestrom, Norway, 1988-1994.

Penner, J. E., C. A. Atherton, and T. Graedel, Global emissions and models of photochemically active compounds, in Proceedings, 1st International Global Atmospheric Biospheric Chemistry, edited by R. G. Prinn, pp. 223-248, Plenum, New York, 1994.

Pham, M., J.-F. Müller, G. Brasseur, C. Granier, and G. Megie, A threedimensional study of the tropospheric sulfur cycle, J. Geophys. Res. 100, 26,061-26,092, 1995.

Pham, M., J.-F. Müller, G. Brasseur, C. Granier, and G. Megie, A 3D model study of the global sulphur cycle: Contributions of anthropogenic and biogenic sources, Atmos. Environ., in press, 1996.

Prather, M. J., M. B. MeElroy, S. C. Wofsy, G. Russell, and D. Rind, Chemistry of the global troposphere: Fluorocarbons as tracers of air motion, J. Geophys. Res., 92, 6579-6613, 1987.

Prospero, J. M., D. L. Savoie, R. Arimoto, H. Olafsson, and H. Hjartarson, Sources of aerosol nitrate and non-sea-salt sulfate in the Iceland region, Sci. Total Environ., 160/161, 181-191, 1995.

Pszenny, A. A., P. F. MacIntyre, and R. A. Duce, Sea salt and the acidity of marine rain on the windward coast of Samoa, Geophys. Res. Lett., 9 751-754, 1982.

Pszenny, A. A., G. R. Harvey, C. J. Brown, R. F. Lang, W. C. Keene, J. N. Galloway, and J. T. Merrill, Measurements of dimethyl sulfide oxidation products in the summertime north Atlantic marine boundary layer Global Biogeochem. Cycles, 4, 367-379, 1990.

Pszenny, A. A. P., W. C. Keene, D. J. Jacob, S. Fan, J. R. Maben, M. P. Zetwo, M. Springer-Young, and J. N. Galloway, Evidence of inorganic chlorine gases other than hydrogen chloride in marine surface air, Geophys. Res. Lett., 20, 699-702, 1993.

Quinn, P. K., T. S. Bates, J. E. Johnson, D. S. Covert, and R. J. Charlson, Interactions between the sulfur and reduced nitrogen cycles over the central Pacific Ocean, J. Geophys. Res., 95, 16,405-16,416, 1990.

Saltzman, E. S., and D. J. Cooper, Shipboard measurements of atmospheric dimcthylsulfide and hydrogen sulfide in the Caribbean and Gulf of Mexico, J. Atmos. Chem.. 7, 191-209, 1988.

Saltzman, E. S., D. L. Savoie, J. M. Prospcro, and R. G. Zika, Atmospheric methanesulfonic acid and non-sea-salt sulfate at Fanning and American Samoa, Geophys. Res. Lett., 12, 437-440, 1985.

Saltzman, E. S., D. B. King, K. Holmen, and C. Leck, Experimental determination of the diffusion coefficient of dimethylsulfide in water, $J$. Geophys. Res., 98, 16,481-16,486, 1993.

Savoie, D, L., and J. M. Prospero, Comparison of oceanic and continental sources of non-sea-salt sulphate over the Pacific Ocean, Nature, 339 , 685-687, 1989.

Savoie, D. L., J. M. Prospero, and E. S. Saltzman, Non-sea-salt sulfate and nitrate in trade wind aerosols at Barbados: Evidence for long-range transport, J. Geophys. Res., 94, 5069-5080, 1989a.

Savoie, D. L., J. M. Prospero, and E. S. Saltzman, Nitrate, non-seasalt sulfate and methane-sulfonate over the Pacific Ocean, in Chemical Oceanography, vol. 10, edited by J. P. Riley, R. Chester and R. A. Duce, pp. 219-250, Academic, San Dicgo, Calif., 1989b. 
Savoie, D. L., J. M. Prospero, R. J. Larsen, F. Huang, M. Izaguirre, T. Huang. T. H. Snowdon, L. Custals, and C. G. Sanderson, Nitrogen and sulfur species in Antarctic aerosols at Mawson, Palmer Station, and Marsh (King George Island), J. Atmos. Chem., 17, 95-122, 1993.

Savoie, D. L., J. M. Prospero, R. Arimoto, and R. A. Duce, Non-sea-salt sulfate and methanesulfonate at American Samoa, J. Geophys. Res., 99. 3587-3596, 1994.

Scala, J. R., et al., Cloud draft structure and trace gas transport, J. Geophys. Res., 95, 17,015-17,030, 1990.

Semb, A., Sulphur emissions in Europe, in Sulfur in the Atmosphere, edited by R. B. Husar, J. P Lodge, and D. J. Moore, pp. 455-460, Pergamon, New York, 1977.

Shaw, R. W., and R. J. Paur, Measurements of sulfur in gases and particles during sixteen months in the Ohio River Valley, Atmos. Environ., 17, 1431-1438, 1983.

Simkin, T., and L. Siebert, Volcanoes of the World: A Regional Directory, Gazetteer, and Chronology of Volcanism During the Last 10,000 Years, 349 pp., Geoscience Press, Tucson, Ariz., 1994.

Spiro, P. A., D. J. Jacob, and J. A. Logan, Global inventory of sulfur emissions with $1^{\circ} \times 1^{\circ}$ resolution, J. Geophys. Res., 97, 6023-6036, 1992.

Spivakovsky, C. M., and Y. J. Balkanski, Tropospheric OH: Constraints imposed by observations of ${ }^{14} \mathrm{CO}$ and methylchloroform, in Report of the WMO-Sponsored Meeting of Carbon Monoxide Experts, edited by P. C. Novelli and R. M. Rosson, Global Atmospheric Watch, World Meteorol. Organ., Geneva, 1994.

Spivakovsky, C. M., R. M. Yevich, J. A., Logan, S. C. Wofsy, M. B. McElroy, and M. J. Prather, Tropospheric $\mathrm{OH}$ in a three-dimensional chemical tracer model: And assessment based on observations of $\mathrm{CH}_{3} \mathrm{CCl}_{3}$, J. Geophys. Res., 95, 18,441-18,472, 1990.

Staubes, R., and H.-W. Georgii, Biogenic sulfur compounds in seawater and the atmosphere of the Antarctic region, Tellus, 45B, 127-137, 1993.

Stoiber, R. E., S. N. Williams, and B. Huebert, Annual contribution of sulfur dioxide to the atmosphere by volcanues, J. Volcunol. Geotherm. Res., 33, 1-8, 1987.

Suhre, K., M.O. Andreae, and R. Rosset, Biogenic sulfur emissions and aerosols over the tropical South Atlantic, 2, One-dimensional simulation of sulfur chemistry in the marine boundary layer, J. Geophys. Res., 100, 11,323-11,334, 1995.

Talbot, R. W., M. O. Andreae, H. Berresheim, P. Artaxo, M. Garstang, R. C. Harriss, K. M. Beecher, and S.-M. Li, Aerosol chemistry during the wet season in central Amazonia: The influence of long-range transport, J. Geophys. Res., 95, 16,955-16,969, 1990.

Tans, P. P., I. Y. Fung, and T. Takahashi, Observational constraints on the global atmospheric $\mathrm{CO}_{2}$ budget, Science, 247, 1431-1438, 1990.

Thornton, D. C., A. R. Bandy, N. Beltz, A. R. Driedger III, and R. Ferek, Advection of sulfur dioxide over the western Atlantic Ocean during CITE 3, J. Geophys. Res., 98, 23,459-23,467, 1993.

Thornton, D. C., A. R. Bandy, B. W. Blomquist, D. D. Davis, and R. W. Talbot, Sulfur dioxide as a source of condensation nuclei in the upper troposphere of the Pacific Ocean, J. Geophys. Res.,101, 1883-1890, 1996.

Toumi, $\mathrm{R} ., \mathrm{BrO}$ as a sink for dimethylsulphide in the marine atmosphere, Geophys. Res. Lett., 21, 117-120, 1994.

Van Valin, C. C., H. Berresheim, M. O. Andreae, and M. Luria, Dimethyl sulfide over the western Atlantic Ocean, Geophys. Res. Lett., 14, 715718, 1987.

Voldner, E. C., L. A. Barrie, and A. Sirois, A literature review of dry deposition of oxides of sulphur and nitrogen with emphasis on long-range transport modelling in North America, Atmos. Environ., 20, 2101-2123, 1986.

Watson, R. T., L. G. Meira Filho, E. Sanhuenza, and A. Janetos, Greenhouse gases: Sources and sinks, in Climate Change 1992, edited by J. T. Houghton et al., WMO/UNEP, Cambridge Univ. Press, New York, 1992.

Wesely, M. L., Parameterization of surface resistance to gaseous dry deposition in regional-scale numerical models, Atmos. Environ., 23, 12931304, 1989.

Wesely, M. L., and B. B. Hicks, Some factors that affect the deposition rates of sulfur dioxide and similar gases on vegetation, J. Air Pollut. Contr. Assoc., 27, 1110-1116, 1977.

Wesely, M. L., D. R. Cook, R. L. Hart, and R. E. Speer, Measurements and parameterization of particulate sulfur dry deposition over grass, I. Geophys. Res., 90, 2131-2143, 1985.

Yvon, S. A., E. S. Saltzman, D. J. Cooper, T. S. Bates, and A. M. Thompson, Atmospheric sulfur cycling in the tropical Pacific marine boundary layer $\left(12^{\circ} \mathrm{S}, 135^{\circ} \mathrm{W}\right)$ : A comparison of field data and model results, 1 , DMS, J. Geophys. Res., 101, 6899-6910, 1996.

Yvon, S. A., and E. S. Saltzman, Atmospheric sulfur cycling in the tropical Pacific marine boundary layer $\left(12^{\circ} \mathrm{S}, 135^{\circ} \mathrm{W}\right)$ : A comparison of field data and model results, 2, $\mathrm{SO}_{2}$, J. Geophys. Res., 101, 6911-6918, 1996.

M. Chin, USRA, NASA Goddard Space Flight Center, Code 916, Greenbelt, MD 20771. (e-mail: chin@gatorl.gsfc.nasa.gov).

S. Foreman-Fowler Program in Atomospheric and Oceanic Sciences, University of Colorado, Boulder, CO 80307. (e-mail: msf@monsoon.colorado.edu).

G. M. Gardner, Division of Engineering and Applied Sciences, and Department of Earth and Planetary Sciences, Harvard University, Cambridge, MA 02138. (e-mail: gmg@1o.harvard.edu).

D.J. Jacob, Division of Engineering and Applied Sciences, and Department of Earth and Planetary Sciences, Harvard University, Cambridge, MA 02138. (e-mail: djj@io.harvard.edu).

D. L. Savoie, Division of Marine and Atmospheric Chemistry, Rosenstiel School of Marine and Atmospheric Scicnec, University of Miami, Miami, FL 33149 .

P. A. Shapiro, Department of Mathematics, University of Utah, Salt Lake City, UT 84112. (e-mail: spiro@math.utah.edu).

(Received July 20, 1995; revised March 8, 1996;

accepted April 9, 1996.) 